\title{
ARTIKELEN
}

\section{Wat betekenen advocaten voor het gezondheidsrecht?}

\section{Confraternele bijdragen voor Willemien Kastelein en Jaap Sijmons}

\author{
Mr. A.C. De Die, Mr. dr. L.A.P. Arends, Mr. W.K. Bischot, Mr. drs. M.J.J. de Ridder, \\ Mr. dr. W.I. Koelewijn, Mr. dr. M.F. Vermaat \& Mr. T.A.M. van den Ende*
}

\section{Inleiding}

Met ingang van 1 april 2021 zijn Willemien Kastelein en Jaap Sijmons geen advocaat meer. Op hetzelfde moment hebben zij afscheid genomen van de redactie van het Tijdschrift voor Gezondheidsrecht.

Kastelein en Sijmons zijn kopstukken van het gezondheidsrecht. Samen bouwden ze tientallen jaren juridische ervaring op, de laatste jaren zelfs bij hetzelfde kantoor. Zij waren betrokken bij honderden juridische procedures, waarvan een flink aantal leidde tot spraakmakende en voor het gezondheidsrecht belangrijke uitspraken. ${ }^{1}$

Advocaten zijn zeer verschillend. Dat gold ook voor Kastelein en Sijmons, toch beoefenaars van hetzelfde rechtsgebied. Willemien: zeer grondig en altijd gepassioneerd, Jaap: een homo universalis met academische overtuigingskracht. Vele vakbroeders en -zusters zullen met plezier denken aan de strijd die ze met of tegen hen leverden. ${ }^{2}$

De redactie besteedt in dit nummer van TvGR onder meer aandacht aan hun vertrek door de vraag te stellen wat de betekenis is van de advocatuur voor het gezondheidsrecht. Wij stelden deze vraag aan zeven gezondheidsrechtelijke advocaten; hun gemotiveerde antwoorden vormen samen dit artikel.

* Mieke de Die is advocaat bij Velink \& De Die advocaten te Amsterdam. Luuk Arends is advocaat bij Dirkzwager te Nijmegen. Willemien Bischot is advocaat bij Van Doorne te Amsterdam. Michel de Ridder is advocaat bij KBS te Utrecht. Wouter Koelewijn is advocaat bij Van Benthem \& Keulen te Utrecht. Matthijs Vermaat is advocaat bij Van der Woude De Graaf te Amsterdam. Tessa van den Ende is advocaat bij Nysingh te Utrecht.

1 Zie daarvoor bijvoorbeeld de voetnoten 4, 37 en 38.

2 Dat geldt in ieder geval voor de samensteller van dit artikel (Joris Rijken). Ik trof Kastelein nooit in rechte, maar Sijmons geregeld (zie bijv. Vzr. Rb. Den Haag 3 november 2010, ECLI:NL:RBSGR:2010:BO2779; CBb 16 maart 2011, ECLI:NL:CBB:2011:BP8470). Zelfs in de meest dorre procedure over tariefbeschikkingen wist hij weidse vergezichten op te roepen - met gebruikmaking van evenzeer weidse armgebaren. 


\section{Wat is het belang van de advocatuur voor het gezondheidsrecht? (A.C. de Die)}

\subsection{Het belang van een goede advocaat}

Ten behoeve van deze bijdrage zou ik de vraag willen herformuleren: wat is het belang van een goede advocaat voor het gezondheidsrecht? Dat Willemien Kastelein en Jaap Sijmons tot de hors categorie advocaten gezondheidsrecht behoren, behoeft wat mij betreft geen betoog. Waar zit 'm dat in? In kennis en ervaring én, net als bij dokters, in de kunst van de beroepsuitoefening. Cliënten zijn blij met mensen die er blijk van geven de materie niet alleen te begrijpen, maar die ook 'boven de stof' staan, overzicht hebben, zaken in perspectief kunnen plaatsen en buitengewoon complexe materie op een inzichtelijke wijze voor het voetlicht kunnen brengen. Jaap Sijmons met zijn reguleringszaken over onderwerpen die maar een handjevol mensen in Nederland bij het $\mathrm{CBb}$ op navolgbare wijze kunnen bepleiten. Willemien Kastelein met haar brede palet van rechtsgebieden als advocaat van artsen in troubles. Cliënten kunnen op hen rekenen en zullen zonder meer op hen vertrouwen. Ook dat is net als bij een dokter: vertrouwen is de basis.

Een goede advocaat is ook een feest voor de rechter: iemand die deugdelijk uitlegt hoe de complexe casus in elkaar zit, vragen adequaat weet te beantwoorden en de zaak juridisch grondig benadert. Niet alleen met kennis van de specifieke gezondheidswetgeving, voor veel rechters toch vaak onbekend terrein, maar ook met oog voor de plaats van het gezondheidsrecht in het grotere geheel van het recht. En, als mr. dr. Sijmons aan het woord is, vaak gelardeerd met de inzichten die de oude filosofen ons al voorhielden.

Dat biedt op zichzelf al meerwaarde, maar de toegevoegde waarde voor het (gezondheids)recht is dat door advocaten als Sijmons en Kastelein grenzen bewaakt, verkend en waar mogelijk verlegd worden. Niet alleen in procedures of complexe adviezen aan cliënten, maar ook in hun vele wetenschappelijke bijdragen en het waken voor aantasting van de waarden van het gezondheidsrecht.

\subsection{Geheimhoudingsplicht}

Een van de oudste waarden in het gezondheidsrecht is het beroepsgeheim dat reeds onderdeel uitmaakte van de Eed van Hippocrates, daterend uit 400 AD:

'Ik zweer bij Apollo de genezer, bij Asklepios, Hygieia en Panakeia en neem alle goden en godinnen tot getuige, om naar mijn beste oordeel en vermogen de volgende eed te houden: (...) Al hetgeen mij ter kennis komt in de uitoefening van mijn beroep of in het dagelijks verkeer met mensen en dat niet behoort te worden rondverteld, zal ik geheim houden en niemand openbaren. (...)'

De zin uit deze oude tekst verschilt niet zo heel veel van het huidige artikel 88 Wet BIG: beroepsbeoefenaren 'zijn verplicht geheimhouding in acht te nemen ten opzichte van al hetgeen wat hem bij het uitoefenen van zijn beroep op het gebied van de individuele gezondheidszorg als geheim is toevertrouwd, of wat daarbij te zijner kennis gekomen of wat daarbij te zijner kennis is gekomen en waarvan hij het vertrouwelijk karakter moest begrijpen'. De huidige artseneed (2003) zegt het kort en bondig: '(...) Ik zal geheim houden wat mij is toevertrouwd.' 
Een oude norm, die in essentie door de eeuwen heen onveranderlijk lijkt te zijn, maar waarover toch veel te doen blijft. Een van de eerste zaken die uit de krochten van de digitale archieven kon worden opgediept was de zaak die door Willemien Kastelein en Cor Spreeuwenberg (toenmalig hoofdredacteur Medisch Contact) van kritisch commentaar werd voorzien. ${ }^{3}$ Het draaide in die zaak om bewijslevering. Een patiënte van een 'inrichting waar lijders aan epilepsie werden verpleegd', was zwanger geraakt. De vraag was van wie? Een verpleegkundige werd als getuige opgeroepen en beriep zich op zijn verschoningsrecht.

Het hof overwoog dat het een inrichting betrof waar gemengde groepen in paviljoens op het terrein van de instelling wonen en ook gezamenlijk op vakantie gaan. Destijds omschreven als 'een maatschappij in de maatschappij'. Het hof achtte niet aanvaardbaar dat onder die omstandigheden alles wat de patiënten op het terrein van de inrichting doen of zeggen door het medisch personeel als zo vertrouwelijk moet worden opgevat dat dit onder hun geheimhoudingsplicht valt. Het beroep op het verschoningsrecht werd afgewezen, onder andere omdat het hof oordeelde dat de geheimhoudingsplicht niet verder gaat dan wat de verpleger heeft vernomen in zijn functie en taakvervulling als verpleger en niet betreft hetgeen hem als wacht gedurende de nacht in de paviljoens ter kennis is gekomen omtrent de intermenselijke relaties (het hof bedoelt: wie seks heeft met wie) tussen de patiënten onderling.

\subsection{Reikwijdte beroepsgeheim en verschoningsrecht}

Kastelein en Spreeuwenberg hielden in Medisch Contact een krachtig pleidooi voor een ruime reikwijdte van het beroepsgeheim. In navolging van Leenen: geen te strikte beperking tot zaken die de gezondheidstoestand betreffen, omdat het in de moderne gezondheidszorg niet steeds om strikt medische aangelegenheden gaat, maar ook om psychosociale aspecten. Daarnaast moet de patiënt zich op alle tijden en plaatsen in vertrouwen tot een hulpverlener kunnen wenden, waarbij ook niet-medische zaken onder de zwijgplicht vallen: anders wordt het beroepsgeheim en de doelstelling daarmee op onaanvaardbare wijze ondergraven. Zij sluiten hun commentaar af met: 'Wij hopen van harte dat een nieuwe uitspraak de nu uitgezette lijn zal doen veranderen. Dit lijkt ons een heilloze weg.'

\subsection{Ontwikkeling jurisprudentie verschoningsrecht}

Hun hoop is werkelijkheid geworden nu de lijn van de jurisprudentie over het verschoningsrecht in de jaren daarna aanzienlijk is aangescherpt en verhelderd. Willemien Kastelein heeft daaraan zelf een wezenlijke bijdrage geleverd door het cassatieberoep in enkele belangrijke zaken. In de eerste zaak werd het beoordelingskader door de Hoge Raad bepaald. ${ }^{4}$ Aan de hand van zes factoren ${ }^{5}$ moet worden beoordeeld of sprake is van 'zeer bijzondere omstandigheden', die meebrengen dat het belang van waarheidsvinding moet

3 Hof Amsterdam 7 november 1988, nr. 1044/86, MC 1989, nr. 7 p. 234-235.

4 HR 29 juni 2004, ECLI:NL:HR:2004:AO5070, NJ 2005/273 m.nt. Knigge.

5 Zie r.o. 5.5 van HR 29 juni 2004. 
prevaleren boven het belang van het verschoningsrecht. Datzelfde beoordelingskader werd nadien veelvuldig toegepast. ${ }^{6}$

In de tweede zaak woog het verschoningsrecht zwaarder omdat niet vaststond dat de gevorderde gegevens niet op andere wijze dan via de verschoningsgerechtigde konden worden verkregen. De hand van de goede advocaat was hier zichtbaar, nu de weigering om de gegevens ter beschikking te stellen niet ongenuanceerd en definitief was, maar afhankelijk werd gesteld van de uitkomst van forensisch onderzoek. Dat maakte uit.?

De derde zaak had betrekking op de gegevens die bij de Huisartsenpost (HAP) bekend waren uit het contact tussen de verdachten en de HAP over het slachtoffer, een kind van 3 jaar, mogelijk overleden als gevolg van kindermishandeling. ${ }^{8}$ Dat de gegevens uit het contact met de HAP binnen de reikwijdte van het (afgeleide) verschoningsrecht vallen, stond niet ter discussie. Na toepassing van het beoordelingskader op de specifieke omstandigheden van het geval, was de conclusie dat het belang van waarheidsvinding zwaarder woog.

Nadien zijn nog enkele arresten gewezen, ${ }^{9}$ waarvan ik nog noem het arrest over de 112melding. ${ }^{10}$ Het zal Willemien Kastelein genoegen doen dat de Hoge Raad in die zaak heeft bevestigd dat de centralist werkzaamheden verricht op het gebied van de individuele gezondheidszorg en dat haar in dit geval ten aanzien van de 112-melding en de daarmee samenhangende gesprekken het recht toekomt zich te verschonen van het geven van informatie.

\subsection{Beroepsgeheim en goede bedoelingen}

Hoewel we Jaap Sijmons als advocaat meestal tegenkomen in de vele zaken die hij heeft gedaan over regulering en ondernemingsrecht in de zorg, laat hij zich op het klassieke leerstuk van het beroepsgeheim ook niet onbetuigd. Recent nog in een tuchtzaak waarin hij een psychiater bijstond. ${ }^{11}$ De psychiater was door de behandelaar van klager gevraagd mee te denken over diagnostiek en behandeling. De psychiater verrichtte psychiatrisch onderzoek en deed verslag van zijn bevindingen aan de behandelaar. Klager verzocht de psychiater om een verklaring, om extra tijd te krijgen voor toetsen op school. De psychiater berichtte de orthopedagoog van de school dat hij klager vanuit zijn rol als psychiater

6 Zie: HR 9 mei 2006, ECLI:NL:HR:2006:AV2386, NJ 2006, 622 m.nt. De Boer en GJ 2006/124 m.nt. Schalken (Savanna); HR 30 oktober 2007, ECLI:NL:HR:2007:BA5611, NJ 2008/115 m.nt. Schalken (notarisarrest); HR 27 mei 2008, ECLI:NL:HR:2008:BC1369, NJ 2008/407 m.nt. Legemaate (apothekersarrest); HR 21 oktober 2008, ECLI:NL:HR:2008:BD7817, NJ 2008, 630 m.nt. Legemaate en GJ 2009/10 m.nt. Schalken (verdachte arts-arrest).

7 HR 26 mei 2009, ECLI:NL:HR:2009:BG5979, NJ 2009/263 m.nt. Legemaate en GJ 2009/82 m.nt. Schalken (LUMC-arrest).

8 HR 28 februari 2012, ECLI:NL:HR:2012:BU6088, NJ 2012/537 m.nt. Legemaate en GJ 2012/49 m.nt. Schalken.

9 HR 10 april 2018, ECLI:NL:HR:2018:553, NJ 2018/435 m.nt. Mevis en GJ 2018/95 m.nt. Schalken; HR 16 juni 2020, ECLI:NL:HR:2020:1048.

10 HR 30 juni 2017, ECLI:NL:HR:2017:1205, NJ 2018/92 m.nt. Vellinga-Schootstra, GJ 2017/129 m.nt. Schalken en GZR 2017-0308 m.nt. De Die.

11 RTG Zwolle 16 maart 2020, ECLI:NL:TGZRZWO:2020:33. 
kent en hem uitvoerig psychiatrisch heeft onderzocht, welke diagnoses zijn gesteld en welke beperkingen hieruit voortvloeien. Zijn reactie had hij niet vooraf aan klager voorgelegd en dat leidde tot de tuchtklacht: schending beroepsgeheim. Klager maakte ook bezwaar tegen bepaalde passages in het verweerschrift met informatie uit het dossier en verzocht om vernietiging.

Dat is door het tuchtcollege niet gehonoreerd. Wel werd de psychiater gevraagd of hij aanleiding zag om reeds ingediende stukken terug te trekken of alsnog een nadere toelichting op de gewraakte stukken te geven. En op zo'n moment heeft de aangeklaagde een goede advocaat nodig, die de implicaties van de bezwaren van klager in het kader van de tuchtprocedure kan overzien en inschatten: wat heeft de beklaagde nodig om adequaat verweer te voeren zonder de klacht te bevestigen of diens positie te verzwakken. De reactie van $\mathrm{mr}$. Sijmons was conform de vaste jurisprudentie dat degene die wordt aangeklaagd, in het kader van zijn verweer gebruik moet kunnen maken van relevante onderdelen van het medisch dossier. ${ }^{12}$ Voor een cliënt, die over het algemeen toch al slecht slaapt vanwege een tuchtklacht, zal een advocaat met kennis van deze vaste jurisprudentie en een standvastige koers een geruststelling zijn.

In reactie op de bezwaren van klager volgde het tuchtcollege - redelijk voorspelbaar - de vaste lijn. In de beoordeling van de klacht is zichtbaar dat het tuchtcollege rekening houdt met de context en de overwegingen van de psychiater. De klacht wordt gegrond verklaard, maar er wordt geen maatregel opgelegd. Ik vermoed zomaar dat goede bijstand hier het verschil heeft gemaakt. Er kan een jaargang van de GJ of Medisch Contact gevuld worden met uitspraken van tuchtcolleges over het afgeven van medische verklaringen met goede bedoelingen, maar met voorbijgaan aan het beroepsgeheim, waarbij de aangeklaagde beroepsbeoefenaar ten minste een waarschuwing opgelegd kreeg. Hier kwam de aangeklaagde weg met de gegrondverklaring en veroordeling tot het voldoen van 2x 50 euro voor reiskosten van klager. Dat zal de psychiater graag op de koop toe hebben genomen.

\subsection{Geheimhouding na overlijden}

Een ander klassiek vraagstuk betreft inzage in het medisch dossier na overlijden. De rechtspraak over inzageverzoeken na overlijden was gevarieerd, maar er ontwikkelde zich een lijn, die uiteindelijk is gecodificeerd in artikel 7:458a BW. ${ }^{13}$ De kern is dat de verzoeker een zwaarwegend belang aannemelijk moet maken, dat dit belang dreigt te worden geschaad en dat inzage noodzakelijk is voor de behartiging van dat belang.

In de periode dat de rechtspraak nog enigszins 'zwabberde' tussen het concept van veronderstelde toestemming van de patiënt en het concept van het zwaarwegend belang speelde de volgende zaak. De echtgenote van een overleden patiënt eiste na zijn overlijden inzage in zijn medisch dossier. De patiënt had zijn echtgenote schriftelijk aangewezen als zijn

12 MTC 's-Gravenhage 6 maart 1991 en CTC 10 april 2003, CT 2002/203 (aangehaald in W.R. Kastelein, Het beroepsgeheim in rechte. Zwijgen: recht of plicht, Het beroepsgeheim, continuiteit en verandering, Preadvies Vereniging voor Gezondheidsrecht, Den Haag: Sdu Uitgevers 2004, p. 157-158); vgl. RTG Eindhoven 13 april 2016, ECLI:NL:TGZREIN:2016:36, waarin wordt bevestigd dat het vaste rechtspraak is.

13 Zie hierover de annotatie van A.C. Beijering-Beck bij Geschilleninstantie Huisartsenzorg Kamer Zuid 15 januari 2019, GJ 2019/76. 
gemachtigde. Deze machtiging was al ruim geformuleerd, maar werd nadien nog verder verruimd. Vanwege de gespannen relatie tussen de echtgenote en de zorginstelling was er kennelijk een onwerkbare situatie ontstaan en is er een aanvraag tot mentorschap ingediend en gehonoreerd, waarbij de kantonrechter niet de echtgenote als mentor benoemde.

$\mathrm{Na}$ overlijden van de patiënt vorderde de echtgenote inzage in medische en zorgdossiers. De rechtbank wees haar vordering toe, uitgaande van veronderstelde toestemming die aan de diverse machtigingen die de echtgenoot bij leven had afgegeven kon worden ontleend. Van de zijde van de zorginstelling was betoogd dat aan de wilsbekwaamheid ter zake van de patiënt getwijfeld kon worden, gelet op zijn geestestoestand. Dat verweer werd afgewezen als onvoldoende onderbouwd.

De onderbouwing van een dergelijk verweer in een zaak als deze brengt natuurlijk wel een duivels dilemma mee: hoe dit aannemelijk te maken, zonder de wederpartij inzage te verschaffen in de onderliggende medische gegevens die juist onderwerp zijn van het geschil? Dat is balanceren op een heel dunne draad. Het tuchtrecht kent daarvoor een oplossing in de vorm van artikel 67 lid 3 Wet BIG. ${ }^{14}$ Artikel 22a Rv ${ }^{15}$, vergelijkbaar met artikel 67 lid 3 Wet BIG, kwam waarschijnlijk net te laat om op basis daarvan bewijs van de wilsonbekwaamheid te leveren zonder eiseres inzage te verschaffen.

Sijmons liep al vooruit op de nieuwe wetgeving door het belang van eiseres te bestrijden, maar dat heeft niet mogen baten. Creatief was vooral het verweer dat de echtgenote gedreven werd door een 'persoonlijke ereschuld'. Wat die zou inhouden is helaas niet uit de uitspraak af te leiden, maar dat mag de lezer aan zijn verbeelding overlaten. ${ }^{16}$

\section{De rol van de advocaat in het tuchtrecht (L.A.P. Arends)}

\subsection{Inleiding}

Menig tuchtrechter fronst het voorhoofd als een zorgverlener zich door een advocaat laat bijstaan tijdens een tuchtprocedure. Sommige voorzitters van Regionale Tuchtcolleges voor de Gezondheidszorg willen daarom tijdens een zitting het pleidooi van de advocaat nogal eens bewaren tot het laatst met de woorden: 'Eigenlijk is nu alles wel aan de orde geweest, maar u mag ook nog wel wat zeggen. Houdt $\mathfrak{u}$ het kort.' Daarmee doen zij de zorgverlener echter tekort. In deze bijdrage licht ik toe waarom.

\subsection{De Wet BIG}

Het werkterrein van het wettelijke tuchtrecht in de gezondheidszorg is met de introductie van de Wet op de beroepen in de individuele gezondheidszorg (Wet BIG) in 1997 uitgebreid van uitsluitend artsen naar alle BIG-geregistreerde beroepen. Jarenlang waren dit

14 Op grond van dit artikellid kan, indien noodzakelijk in verband met de privacy van derden, de voorzitter van het tuchtcollege bepalen dat kennisneming van (delen van) processtukken niet aan klager persoonlijk wordt toegestaan, maar uitsluitend aan een gemachtigde (arts, advocaat of met toestemming van de voorzitter).

15 Stb. 2016, 288, inwerkingtreding 1 mei 2017.

16 Rb. Oost-Brabant 22 november 2017, ECLI:NL:RBOBR:2017:6092. 
'slechts' de artsen, tandartsen, apothekers, gezondheidszorgpsychologen, fysiotherapeuten, verloskundigen en verpleegkundigen, maar inmiddels zijn daarbij gekomen de physician assistant, de orthopedagoog-generalist en sinds 1 juli 2020 ook de klinisch technoloog.

Met de introductie van de Wet BIG werd de tuchtrechtspraak in de gezondheidszorg openbaar, net als bij advocaten en notarissen. Een van de redenen daarvoor was dat bij tuchtrechtelijke procedures 'sancties kunnen worden opgelegd die diep ingrijpen in de beroepsuitoefening, zo niet deze feitelijk kunnen uitsluiten, een burgerlijk recht in de zin van het Verdrag kunnen betreffen'. ${ }^{17}$ Hierbij werd gedoeld op het Europees Verdrag van de Rechten van de Mens, in het bijzonder artikel 6 EVRM. Hoewel zeker een overeenkomst bestaat met het strafrecht, is het doel van het tuchtrecht volstrekt anders. Waar het strafrecht 'een afschrikwekkend doel en het doel om te vergelden' heeft, staat in het tuchtrecht 'het bewaken en bevorderen van de kwaliteit van de beroepsuitoefening' voorop..$^{18}$ En daarbij gaat het erom dat de door de beroepsgroep zelf vastgestelde normen gehandhaafd worden en daarmee de kwaliteit, integriteit en discipline van de groep worden gewaarborgd. ${ }^{19}$

\subsection{Recht op vertegenwoordiging door een gemachtigde of raadsman}

Desalniettemin is het ingrijpende karakter van tuchtrechtprocedures gegeven en de toepasselijkheid van artikel 6 EVRM terecht. In het verlengde hiervan bepaalde voorheen artikel 65 lid 9 Wet BIG en bepaalt thans artikel 65e Wet BIG, dat zowel de klager als de beklaagde zich kunnen laten vertegenwoordigen door een gemachtigde en zich kunnen laten bijstaan door een raadsman. Een advocaat moet altijd worden toegelaten als gemachtigde of raadsman. In andere gevallen kan de gemachtigde/raadsman wél geweigerd worden. Dit mag echter slechts als er duidelijke aanwijzingen zijn dat door de toelating van die persoon een behoorlijke uitoefening van de tuchtrechtspraak zal worden belemmerd. Een niet-advocaat dient desgevraagd een schriftelijke volmacht te kunnen overleggen.

Het recht op bijstand door een advocaat (of andere gemachtigde) is dus verankerd in het tuchtrecht. Dat is eigenlijk ook hard nodig. Zo eenvoudig is het tuchtrecht immers niet voor de doorsnee zorgverlener. Er zijn namelijk nogal wat processuele regels die voor een niet-jurist knap ingewikkeld zijn.

\subsection{De klager als 'rechtstreeks belanghebbende'}

Dat geldt allereerst voor het begrip 'rechtstreeks belanghebbende'. Niet elke zorgverlener zal weten dat niet iedere klager rechtstreeks belanghebbende zal zijn. Zo is een curator bijvoorbeeld in de regel rechtstreeks belanghebbende, maar niet ontvankelijk als klager als de curandus wilsbekwaam is en met de klacht niet (duidelijk) instemt. ${ }^{20}$ Overigens dient een rechtstreeks belanghebbende als hij niet de patiënt is altijd een duidelijke vermelding te geven van de reden waarom hij als zodanig te gelden heeft (art. 4 lid 1 onder b Tuchtrechtbesluit BIG). Een tuchtcollege hoort ambtshalve te toetsen of iemand als rechtstreeks belanghebbende kwalificeert, maar zal niet altijd alle aspecten die iemand wel of niet recht- 
streeks belanghebbende maken op voorhand doorgronden. Een advocaat kan in dit verband een welkome bijdrage leveren aan de rechtsvorming.

\subsection{De twee tuchtnormen}

De omvang van de tuchtprocedure wordt bepaald door de normen die de wet hanteert. De wet kent er twee: (a) het handelen of nalaten in strijd met de zorg die een geregistreerde beroepsbeoefenaar als beroepsbeoefenaar dient te betrachten en; (b) enig ander handelen of nalaten in strijd met hetgeen behoorlijk beroepsbeoefenaar betaamt (art. 47 lid 1 Wet BIG). Volgens de wetgever legt het tuchtcollege deze normen terecht ruim uit. Volgens de wetgever is dit in lijn met het doel van het tuchtrecht. ${ }^{21} \mathrm{Zo}$ is de wetgever van oordeel dat zeden- en geweldsdelicten begaan door een geregistreerde beroepsbeoefenaar in de privésfeer onderhevig zijn aan tuchtrecht als er daarbij sprake is van gedragingen die een gevaar voor patiënten kunnen opleveren of die het vertrouwen in de beroepsuitoefening ernstig kunnen schaden. De grens tussen wanneer een delict in de privésfeer het vertrouwen in de beroepsuitoefening ernstig zou schaden of een gevaar voor patiënten zou opleveren en wanneer niet, valt niet altijd duidelijk te trekken, waardoor er een gevaar voor willekeur is. Een advocaat kan aan het zuiver trekken van die grens een relevante bijdrage leveren.

Leidinggevenden die tevens BIG-geregistreerd zijn kunnen sinds de standaarduitspraak van het Centraal Tuchtcollege in 2011 tuchtrechtelijk aangesproken worden voor zover de gedragingen voldoende weerslag hebben op de individuele gezondheidszorg. ${ }^{22}$ Daar staat tegenover dat zij niet aangesproken behoren te worden voor zaken waarvoor hen beleidsvrijheid toekomt. Het is niet de bedoeling dat het tuchtcollege op de stoel van de beroepsbeoefenaar als leidinggevende gaat zitten. Met de gewijzigde tuchtnorm heeft de wetgever het de tuchtrechter er in dit verband niet gemakkelijker op gemaakt.

Enerzijds heeft hij met de wijziging beoogd dat ook gedragingen die niet zijn begaan in de hoedanigheid van geregistreerde nadrukkelijk(er) onder het tuchtrecht kunnen vallen. Het tuchtrecht is daardoor ook van toepassing als een BIG-geregistreerde binnen of buiten de zorg in de uitoefening van een ander beroep dan waarvoor hij geregistreerd is (beroepsmatig) handelt in strijd met de beroepsnormen waarvoor hij wél geregistreerd is. ${ }^{23}$ In dit verband wordt het door de tuchtrechtspraak ontwikkelde weerslagcriterium door de wetgever overigens nadrukkelijk onderschreven. ${ }^{24}$

Anderzijds houdt dit in dat de beroepsbeoefenaar - bijvoorbeeld als leidinggevende daarbij nog steeds iets moet doen of nalaten wat hem als (behoorlijk) geregistreerde beroepsbeoefenaar verweten kan worden. Voor bijvoorbeeld het waarborgen van goede zorg met betrekking tot het handelen als bestuurder van een zorgorganisatie gelden immers andere instrumenten, zoals het toezicht door IGJ op grond van de Wkkgz. Een advocaat kan eraan bijdragen dat de geregistreerde beroepsbeoefenaar louter als geregistreerde beroepsbeoefenaar wordt aangesproken. 


\subsection{De klacht en het verweer}

De inhoud van een specifieke tuchtprocedure wordt bepaald door de klacht. Deze wordt vormgegeven door de aard en omvang van het klaagschrift. Het klaagschrift dient de klacht te bevatten, alsmede de feiten en gronden waarop deze berust (art 2 lid 1 onder b Tuchtrechtbesluit). Wie zijn klacht naderhand tot andere delen van de zorgverlening wilde uitbreiden kon dat tot voor kort formeel niet, al stond de tuchtrechter in de afgelopen jaren dit wel in toenemende mate toe.

In artikel 65c Wet BIG is deze mogelijkheid thans verankerd: de klager kan zijn klacht wijzigen of aanvullen tot twee weken voor de behandeling ter terechtzitting. De beklaagde dient in de gelegenheid te worden gesteld te worden gehoord over de wijziging dan wel de aanvulling van de klacht. Uiteraard dient hij tevens voldoende in de gelegenheid te zijn inhoudelijk op de klacht te kunnen reageren. Aan dit aspect wordt in de wet en de toelichting weinig aandacht geschonken. Dit is ter beoordeling van het tuchtcollege. Ook hier kan de advocaat eraan bijdragen dat aan wederhoor voldoende recht wordt gedaan.

\subsection{De inhoudelijke beoordeling door het tuchtcollege}

Buiten de processuele aspecten van de zaak is daar natuurlijk ook de inhoud. Het gaat om het beoordelen van het handelen van een specifieke BIG-geregistreerde beroepsbeoefenaar. Deze beoordeling dient zorgvuldig te gebeuren, waarbij belangrijk is dat de beoordelaars voldoende expertise in huis hebben. Lid zijn van dezelfde beroepsgroep is niet voldoende: een verpleegkundige in de ouderenzorg heeft niet dezelfde kennis en kunde als een ambulanceverpleegkundige en er gelden ook niet dezelfde normen. Een klinisch geriater in het ziekenhuis richt zich wellicht op dezelfde doelgroep als een specialist ouderengeneeskunde, maar in het ziekenhuis worden andere afwegingen gemaakt met betrekking tot de zorgverlening dan in het verpleeghuis waarvoor andere normkaders gelden of kunnen gelden. Een advocaat kan eraan bijdragen dat de juiste normen gehanteerd worden en zo nodig externe deskundigen bij de behandeling van de zaak betrekken.

\subsection{De advocaat is méér dan een jurist}

Tuchtzaken hebben een enorme impact op de zorgverlener die wordt aangesproken. Weliswaar wordt zijn beroepsmatig handelen getoetst, maar hij wordt persoonlijk aangesproken. Bij veel zorgverleners komt dit hard aan. Beroepsmatig handelen kan met de wetenschap van achteraf altijd beter. Dat brengt vaak onzekerheid met zich. Een advocaat is dan niet alleen jurist, maar ook in andere opzichten raadsman of -vrouw. Sommige tuchtcolleges leggen soms grote druk op een zorgverlener om bij de behandeling van een zaak ter terechtzitting in te stemmen met een vervanger omwille van de voortgang van de procedure als hun advocaat niet kan. Daarmee doen zij deze zorgverleners echter tekort. Een vervanger is niet de vertrouwenspersoon met wie zij in zee zijn gegaan en kan de zaak niet zo goed kennen als de oorspronkelijke behandelaar. Het opleggen van een dergelijke druk kan in strijd komen met artikel 6 EVRM.

\subsection{Tot slot: de bijdragen van Kastelein en Sijmons}

Advocaten komen elkaar in tuchtzaken sporadisch tegen. Soms gebeurt dit wanneer zowel klager als beklaagde zich door een advocaat laten bijstaan. Vaker gebeurt het wanneer een 
patiënt meerdere zorgverleners van verschillende zorginstellingen heeft aangesproken. Hoewel mijn pad dat van Willemien Kastelein en Jaap Sijmons in mijn werkzaamheden als advocaat vaker heeft gekruist, ben ik ze in tuchtrechtprocedures vrijwel nooit echt tegengekomen.

Dat neemt niet weg dat zij allebei van (veel) betekenis zijn (geweest) voor de ontwikkeling van het tuchtrecht, als advocaat en als wetenschapper. Sijmons was de kartrekker van de tweede evaluatie van de Wet BIG en het tuchtrecht in 2013.25 Kastelein schreef vele artikelen over het tuchtrecht ${ }^{26}$ en was bij nog veel meer procedures direct of indirect betrokken. Het invoeren van haar naam als trefwoord op tuchtrecht.overheid.nl (gezondheidszorg) levert maar liefst 453 resultaten op. Waarschijnlijk heeft geen enkele andere advocaat zo veel tuchtzaken op zijn naam staan. Een aantal daarvan heeft ook met zekerheid bijgedragen aan de rechtsvorming.

Bij de enkele keer dat ik Kastelein in tuchtzaken tegenkwam, toonde zij zich gedegen, principieel, bevlogen en betrokken, waarmee zij zich een lichtend voorbeeld heeft getoond van hoe een advocaat als jurist en als hulpverlener een betrokkene kan bijstaan in een tuchtrechtprocedure. Een dergelijke inzet draagt bij aan de kwaliteit van het tuchtrecht. Ook in de toekomst dienen tuchtcolleges daarvoor ruimte te blijven bieden en wel door advocaten ook tijdens de zitting voldoende aan het woord te laten. Voor de rechtsvorming, maar ook om degenen die zij bijstaan het gevoel te geven dat ze er niet alleen voor staan.

\section{De zaak Tuitjenhorn, met vereende krachten vechten voor rechtsbescherming! (W.K. Bischot)}

\subsection{Inleiding}

Begin oktober $2013 \mathrm{kwam}$ in het nieuws dat een huisarts werd verdacht van onzorgvuldig levensbeëindigend handelen. ${ }^{27}$ Achter dit nieuws gaat een persoonlijk drama schuil, dat is uitgemond in de zelfmoord van de betrokken huisarts en grote maatschappelijke commotie over het handelen van diverse betrokkenen.

Gepaard met de maatschappelijke onrust ging, zoals zo vaak, een aantal juridische vraagstukken die niet alleen voor de direct betrokkenen van grote invloed zijn geweest, maar ook voor het gezondheidsrecht in het algemeen. Jaap Sijmons en Willemien Kastelein hebben van meet af aan samen de betrokken huisarts en later zijn weduwe bijgestaan en daarmee niet alleen een belangrijke rol gespeeld bij de rechtsvorming rond deze zo verdrietige casus, maar daarnaast ook een andere belangrijke rol van de advocaat vervuld, te weten het bieden van morele ondersteuning aan de cliënt in een moeilijke tijd.

25 J.G. Sijmons et.al. Tweede evaluatie Wet op de beroepen in de individuele gezondheidszorg, Den Haag: ZonMw, oktober 2013.

26 Enkele voorbeelden: W.R. Kastelein, 'Tucht of recht? De BIG en het tuchtrecht', TvGR 1991, afl. 6; 'Tuchtrecht in de Wet BIG; ervaringen 1997-2000', TvGR 2000, afl. 7,en de vele kronieken rechtspraak tuchtrecht in dit tijdschrift van haar hand.

27 Vgl. Medisch Contact 4 oktober 2013, www.medischcontact.nl/nieuws/laatste-nieuws/artikel/huisartsverdacht-van-onzorgvuldige-euthanasie.htm. 
De zaak kan worden beschouwd vanuit verschillende juridische invalshoeken. Daarnaast vanuit het perspectief van de 'publieke' opinie ${ }^{28}$, die een belangrijke bijdrage heeft geleverd aan het ontsporen van een zaak die wel heel impactvol, maar in de kern juridisch niet zo ingewikkeld was. ${ }^{29}$

Het bestuursrechtelijke kader, dat in 2013 nog werd gevormd door de Kwaliteitswet zorginstellingen (Kwaliteitswet), is in rechte 'to the test' gekomen naar aanleiding van het door de Inspectie Gezondheidszorg en Jeugd $(\mathrm{IG})^{30}$ ) aan de huisarts opgelegde bevel. Dit bevel heeft Jaap Sijmons voor de huisarts en later zijn weduwe in bezwaar, beroep en hoger beroep - uiteindelijk met succes - aangevochten.

Daarnaast heeft het strafrechtelijk kader tot aan het overlijden van de huisarts een cruciale rol gespeeld bij het verloop van de zaak. Dit is het domein van Willemien Kastelein.

De twee kaders zijn in het bijzonder relevant waar het betreft de ingezette middelen om te zorgen dat de huisarts hangende het onderzoek geen (palliatieve) zorg zou verlenen. Daaruit blijkt ook wat de rol van Willemien en Jaap is geweest, althans had kunnen zijn, bij het beantwoorden van de rechtsvragen die zich hebben voorgedaan en daarnaast - misschien wel belangrijker - in het kader van de ondersteuning van en de uitkomst voor hun cliënten.

\subsection{De feiten ${ }^{31}$}

In Tuitjenhorn houdt een huisarts samen met zijn echtgenote in maatschapsverband praktijk. De huisarts is tevens opleider in het kader van de opleiding geneeskunde van de UvA. Uit dien hoofde heeft hij in de praktijk een coassistent. In augustus 2013 bezoekt hij samen met deze coassistent een terminaal zieke patiënt, aan wie hij morfine en dormicum toedient, in hoeveelheden die afwijken van de gangbare medische praktijk, waarna de patiënt snel overlijdt.

De coassistent maakt van de handelwijze van de huisarts melding bij haar coschapcoördinator, die de situatie (in eerste instantie anoniem) voor advies voorlegt aan de IGJ. Dat brengt de bal hard aan het rollen. De IGJ licht het openbaar ministerie in, ${ }^{32}$ dat onmiddellijk een strafrechtelijk onderzoek naar de huisarts start.

Voor dit artikel met name van belang zijn de acties van IGJ en OM die volgden en erop waren gericht om gevaar voor herhaling hangende het onderzoek tegen te gaan. Het zijn deze acties waar Jaap Sijmons en Willemien Kastelein tegen zijn opgekomen, dan wel naar

28 In deze zaak vooral bepaald door de opinie van huisartsen in den lande en hun beroepsvereniging, de LHV.

29 Dat het OM dat ook vond, blijkt uit het feit dat het Expertisecentrum Medische Zaken (EMZ) de zaak direct na binnenkomst direct doorverwees naar het regionaal parket.

30 Toen nog Inspectie voor de Gezondheidszorg (IGZ) geheten.

31 Vgl. voor een chronologisch feitenoverzicht over de periode vanaf eind augustus tot eind oktober 2013 het 'Rapport van de Evaluatiecommissie Tuitjenhorn', maart 2015 (p. 8 en 9) (hierna: Evaluatierapport), www.rizoomes.nl/wp-content/uploads/2013/09/Rapport-Tuitjenhorn-Bleichrodt.pdf. 
verwachting hadden zullen opkomen als het strafrechtelijk onderzoek niet zou zijn geëindigd als gevolg van het overlijden van de huisarts. ${ }^{33}$

Het zijn ook deze acties die in de onafhankelijke evaluatie van het handelen van alle betrokken instanties, die in opdracht van de Minister van VWS is gedaan door een commissie onder leiding van C.J.G. Bleichrodt (hierna: Commissie Bleichrodt), kritisch zijn beoordeeld. Deze evaluatie is in maart 2015 uitgemond in een evaluatierapport. ${ }^{34}$

\subsection{Het bevel van de IGJ}

De IGJ heeft in eerste instantie geen eigen onderzoek gedaan, maar de uitkomsten van het strafrechtelijk onderzoek afgewacht. ${ }^{35}$ In de uitkomst daarvan heeft zij vervolgens aanleiding gezien om op 2 oktober 2013 een op artikel 8 lid 4 Kwaliteitswet gestoeld bevel uit te vaardigen. ${ }^{36}$ Doel van het bevel was te beletten dat de huisarts weer zorg zou gaan verlenen. Het bevel is gericht aan de huisarts en diens praktijk.

De IGJ motiveert het bevel met een verwijzing naar het strafrechtelijk onderzoek, waaruit zou blijken dat de huisarts ernstig in strijd heeft gehandeld met de norm van verantwoorde zorg, die de basis is van de Kwaliteitswet.

De huisarts en zijn praktijk hebben bezwaar gemaakt tegen het bevel. De bezwaarprocedure is na het overlijden van de huisarts namens de praktijk voortgezet. In die procedure adviseert de interne bezwaarcommissie van VWS de IGJ het bezwaar gegrond te verklaren omdat het bevel onrechtmatig was, in verband met twee redenen:

- Er was geen sprake van het voor toepassing van artikel 8 lid 4 noodzakelijke gevaar voor de veiligheid of gezondheid, waardoor het nemen van maatregelen redelijkerwijs geen uitstel kon lijden. Anders gezegd: er was in oktober voldoende tijd om te wachten op een aanwijzing van de minister op grond van lid 1 van hetzelfde artikel.

- De reikwijdte van het bevel was disproportioneel ruim. Het was voldoende geweest om de huisarts en zijn praktijk te beperken in het bieden van palliatieve en terminale zorg en euthanasie.

De IGJ volgt de adviescommissie niet en laat het bevel in bezwaar (groten)deels in stand. De rechtbank geeft de IGJ daarin in beroep nog gelijk, ${ }^{37}$ maar de Afdeling bestuursrechtspraak van de Raad van State overweegt in hoger beroep dat geen sprake was van een situatie waarin het nemen van maatregelen geen uitstel kon lijden, als gevolg waarvan het bevel onrechtmatig was. ${ }^{38}$ Aan een oordeel over de vraag of er inhoudelijk grond was voor een bevel komt de Afdeling niet toe.

33 Het recht op strafvordering verviel door dit overlijden o.g.v. art. 69 Sr.

34 Vgl. noot 31.

35 Wel waren bijzondere opsporingsambtenaren van de IGJ aan het opsporingsteam toegevoegd.

36 De huisarts is gehoord over het voornemen en heeft daarop - bij monde van Sijmons - een schriftelijke zienswijze gegeven. Vervolgens is het bevel opgelegd en gedeeltelijk openbaar gemaakt.

37 Vgl. Rb. Noord-Holland 2 juli 2015, ECLI:NL:RBNHO:2015:5480 en A.C. De Die, o.a. over de uitspraak van de rechtbank, TvGR 2015/8, 'De casus Tuitjenhorn'.

38 Vgl. ABRvS 1 juni 2016, ECLI:NL:RVS:2016:1502, TvGR 2017/1 m.nt. M.E.F. Bots en AB 2016/230 m.nt. A.C. Hendriks. 


\subsection{De vordering bewaring van het $\mathrm{OM}$}

Vlak na de IGJ verbond ook het OM consequenties aan de uitkomsten van het strafrechtelijk onderzoek door de rechter-commissaris op 7 oktober 2013 te vragen de huisarts in bewaring te stellen. ${ }^{39}$ Doel van dit verzoek was de kans op herhaling in te perken. Om dit doel te bereiken was onderdeel van het verzoek een schorsing van de bewaring onder de bijzondere voorwaarde dat de huisarts zich zou onthouden van palliatieve zorg en euthanasie. De rechter-commissaris wijst het verzoek toe.

Opmerkelijk is dat het verzoek wordt gedaan en toegewezen nádat het verderstrekkende bevel van de IGJ al is ingegaan. Uit het Evaluatierapport blijkt dat hierover geen afstemming heeft plaatsgevonden tussen IGJ en OM en evenmin duidelijk is geworden waarom het OM het nodig vond om 'dubbel te stikken', anders dan dat het OM vond dat hij een eigen verantwoordelijkheid heeft in het kader van maatschappelijke veiligheid..$^{40}$

Feit is wel dat de huisarts op de dag na de inbewaringstelling zelfmoord pleegt. Dat heeft er de schijn van dat de bewaring de bekende druppel is geweest.

De Commissie Bleichrodt is terecht kritisch op het handelen van het OM. Dat had het preventiebeleid aan de IGJ moeten laten - overeenkomstig de afspraak dat bestuursrechtelijk handelen in principe voorrang heeft boven inzet van strafrechtelijke middelen - en het wederzijdse beleid met de IGJ moeten afstemmen. Letterlijk overweegt de Commissie: 'Een enkele maatregel was in deze omstandigheden al ingrijpend genoeg, twee gelijksoortige maatregelen was zeker te veel van het goede. Afstemming zou dit hebben voorkomen.'

\subsection{Conclusie}

In deze zaak is het bevel van de IGJ in twee instanties 'to the test' gekomen, in door Jaap gevoerde procedures. De uitkomst van de toets van het bevel is in juridisch opzicht niet bijzonder of onverwacht.

Beide annotatoren van de uitspraak in hoger beroep zijn het erover eens dat de Afdeling bestuursrechtspraak terecht oordeelt dat de IGJ ten onrechte heeft gemeend dat het nemen van de maatregel redelijkerwijs niet kon wachten op het geven van een aanwijzing, ${ }^{41}$ in het licht van de ziekte van de huisarts en de gedane toezegging - met betrokkenheid van zijn advocaat - dat hij niet zou gaan werken zonder voorafgaande melding aan de IGJ.

Was de uitspraak niet onverwacht, de impact ervan voor de weduwe van de huisarts was des te groter. Deze heeft immers de deur opengezet voor het treffen van een schikking en die is er-uiteindelijk - ook gekomen. ${ }^{42}$

Het handelen van het $\mathrm{OM}$ is niet getoetst en dat is jammer, omdat daardoor de vraag of de vordering tot bewaring, op een moment waarop het doel daarvan al op een andere manier was gediend, de toets der kritiek wel kon doorstaan niet is beantwoord. Willemien Kaste-

39 Op de voet van art. 63 jo. 64 (bewaring) en art. 80 (schorsing) Sr.

40 Vgl. in breder strafrechtelijk perspectief P.A.M. Mevis, 'Naar aanleiding van Tuitjenhorn', DD 2014/8.

41 Door de Minister van VWS o.g.v. lid 1 van art. 8 Kwaliteitswet.

42 Vgl. www.rijksoverheid.nl/binaries/rijksoverheid/documenten/kamerstukken/2018/09/14/kamerbrief-overcasus-tuijtenhorn/kamerbrief-over-casus-tuijtenhorn.pdf. 
lein had haar antwoord op die vraag denk ik met verve verdedigd. Ze had daarbij goed gebruik kunnen maken van de overwegingen van de Commissie Bleichrodt over de vordering. ${ }^{43}$

Wat is er nu veranderd door het betrokken adviseren en vasthoudend procederen door Sijmons en Kastelein, waardoor een vergelijkbare zaak in de toekomst beter zou kunnen aflopen?

- In elk geval zullen IGJ en OM een volgende keer beter moeten afstemmen wie wat doet en wat en hoe zij daarover communiceren. Het Samenwerkingsprotocol is aangescherpt en voorziet nu in de verplichting om in geval van samenloop van toezichthandelen en opsporingsonderzoek een gezamenlijk plan van aanpak op te stellen. ${ }^{44}$

- Naar verwachting zal de uitkomst van die afstemming zijn dat maatregelen om herhaling te voorkomen door de een óf de ander worden genomen en zal het OM de IGJ in beginsel voor moeten laten.

- Verder ligt er een heldere uitspraak van de Afdeling over de uitleg van artikel 8 lid 4 Kwaliteitswet die doorwerkt naar artikel 27 lid 4 Wkkgz. ${ }^{45}$ Deze uitspraak zal maken dat de IGJ een volgende keer beter beoordeelt of zij kan grijpen naar het bevel, of (eerst) een andere, met betere waarborgen omklede weg zal moeten volgen.

- Of de genoegdoening die de weduwe van de huisarts heeft gekregen in de vorm van een schikking een precedent schept is de vraag, omdat de IGJ in dat kader geen aansprakelijkheid heeft erkend en de vraag of sprake was van causaal verband tussen de onrechtmatigheid en schade niet (in het openbaar) is gevoerd. Dat die discussie haken en ogen had, gelet op alle omstandigheden van de zaak, hoeft geen betoog.

\subsection{Slotopmerking}

Het meest opvallend heb ik persoonlijk gevonden dat het accent in deze zaak, mede maar niet alleen als gevolg van het overlijden van de huisarts, volledig is verschoven van een toets van het handelen van de huisarts, naar een toets van het handelen van IGJ en OM en andere bij de zaak betrokken instanties en beroepsorganisaties.

Dit handelen werd in de publiciteit, vooral door collega-huisartsen en door de LHV, hard veroordeeld zonder kennis van het handelen van de huisarts waarop door de instanties werd gereageerd. Toen de feiten wel bekend werden ${ }^{46}$ en ook het oordeel van de Commissie Bleichrodt, nam het aantal tegengeluiden wel toe, maar bleef de teneur pro huisarts.

In het bestek van dit artikel is de interessante vraag of de advocatuurlijke ondersteuning van Jaap en Willemien en de strategische keuzes die zij daarbij hebben gemaakt hieraan

43 Vgl. Evaluatierapport ibid., par. 2.4.6, p. $32 \mathrm{t} / \mathrm{m} 34$.

44 Het 'Samenwerkingsprotocol gezondheidszorg 2015' met als bijlage B de aangepaste informatieparagraaf waarin op p. 8 het verplichte plan van aanpak, vgl. IGJ en OM vernieuwen hun Samenwerkingsprotocol. Vgl. ook De Die in TvGR 2015/8.

45 De Wet kwaliteit, klachten en geschillen zorg, die per 1 januari 2016 de Kwaliteitswet heeft vervangen.

46 Onder andere door publicatie van het verslag van de coassistent in de Volkskrant op 26 oktober 2013. www.volkskrant.nl/nieuws-achtergrond/zo-veel-morfine-dat-is-geen-palliatieve-sedatie-meer b009dd39/. 
heeft bijgedragen. Dat is van buitenaf vanzelfsprekend niet goed te beoordelen, omdat wij de afwegingen en gemaakte keuzes niet kennen. ${ }^{47}$

In elk geval kan gezegd worden dat de keuze om het bevel van de IGJ aan te vechten en dit gevecht voort te zetten na het overlijden van de huisarts belangrijke gevolgen heeft gehad, zowel voor de beeldvorming rond de huisarts als in financiële zin voor zijn weduwe.

Het oordeel van de Afdeling bestuursrechtspraak over het bevel was immers het eerste en enige moment waarop het handelen van de IGJ werd veroordeeld. Het feit dat - drie jaar na dato - kwam vast te staan dat het bevel onrechtmatig was, bood niet alleen een vorm van emotionele genoegdoening voor de weduwe van de huisarts, het was ook de opmaat voor de mogelijkheid om de IGJ te dwingen haar een financiële compensatie te betalen. Zonder de vasthoudendheid van Jaap in hoger beroep was dat niet gelukt.

Aan de positieve beeldvorming heeft Jaap verder bijgedragen door zijn medewerking te verlenen aan een documentaire, waarin de weduwe haar verhaal heeft kunnen vertellen. ${ }^{48}$ Daarnaast hebben de excuses die de IGJ heeft gemaakt en het interview dat inspecteurgeneraal Ronnie van Diemen gaf na afloop ${ }^{49}$ ongetwijfeld ook deels hun oorsprong in de afspraken die onder de bezielende leiding van Jaap zijn gemaakt.

\section{5. 'Bewijsgaring' in het belang van een goede rechtsbedeling (M.J.J. de Ridder)}

\subsection{Inleiding}

Artikel 10a Advocatenwet bepaalt dat een advocaat in het belang van een goede rechtsbedeling de gerechtvaardigde belangen van zijn cliënt behartigt. Hij is daarbij: onafhankelijk, partijdig, deskundig, integer en een vertrouwenspersoon. Dit worden de 'kernwaarden' van de advocatuur genoemd. ${ }^{50}$ Deze kernwaarden zijn niet alleen in de rechtszaal zeer belangrijk, maar ook in de fase die daaraan voorafgaat, bijvoorbeeld tijdens onderhandelingen en bewijslevering.

Bij de taak van een advocaat om het benodigde bewijs te verzamelen komt dat in het bijzonder tot uitdrukking: hij dient op basis van zijn deskundigheid na te gaan welke bewijsmiddelen voorhanden zijn, welke bewijswaarde daaraan kan worden toegekend en welk aanvullend bewijs ter onderbouwing van het standpunt van zijn cliënt nodig is, op welke wijze dat bewijs kan worden verkregen. Dat geldt vooral als een advocaat de eisende partij bijstaat. Op die partij rust immers de stelplicht en bewijslast.

Op het gebied van het medische aansprakelijkheidsrecht geldt dat echter ook voor de verwerende partij. Sinds het Timmer/Deutman-arrest uit $1988^{51} \mathrm{kan}$ de advocaat van de hulp-

47 Willemien Kastelein heeft zich in het kader van het onderzoek door de Commissie Bleichrodt op haar geheimhoudingsplicht beroepen (vgl. p. 5 Evaluatierapport) en (ook) daar haar visie op de zaak niet kenbaar kunnen maken.

48 Vgl. 'De zaak Tuitjenhorn', EO, 6 mei 2019 www.2doc.nl/documentaires/series/2doc/2019/mei/de-zaaktuitjenhorn0.html.

49 Vgl. MC 20 september 2018, 'Lessen leren van de zaak-Tuitjenhorn'.

50 'Kernwaarden van de advocatuur' (zie www.advocatenorde.nl/juridische-zaken/kernwaarden).

51 HR 20 november 1987, ECLI:NL:HR:1987:AD0058 (Timmer/Deutman); NJ 1988, 500 m.nt. W.L. Haardt. 
verlener niet meer (rustig) afwachten met welk bewijs de patiënt komt. De arts dient, aldus de Hoge Raad, de patiënt voldoende feitelijke gegevens te verstrekken ter motivering van zijn betwisting van de aansprakelijkheid teneinde de patiënt aanknopingspunten te bieden voor eventuele bewijslevering. Met deze verzwaarde stelplicht wordt de bewijslast van de patiënt verlicht en de zogeheten informatieasymmetrie tussen arts en patiënt hersteld.

\subsection{HR 16 maart 1998 (Tangverlossing)}

Illustratief is het arrest 'tangverlossing' van de Hoge Raad van 16 maart 2018. ${ }^{52}$ Het ging in die zaak om een baby die op 29 september 2005 door middel van een keizersnede in het Waterlandziekenhuis werd geboren. Daarbij werd het hoofdje met een tang (forceps) geboren. Na zijn geboorte werd de baby overgebracht naar het VUMC, alwaar op 31 oktober 2005 een dwarslaesie werd vastgesteld. De moeder stelde zich op het standpunt dat dit een gevolg was van een beroepsfout van de gynaecoloog tijdens het hanteren van de tang.

De rechtbank benoemde twee deskundigen: een hoogleraar gynaecologie en een hoogleraar kinderneurologie. De gynaecologisch deskundige concludeerde dat de dwarslaesie zou kunnen zijn veroorzaakt door een nog vóór de geboorte opgelopen coxsackievirusinfectie én dat hij geen aanwijzingen had om te twijfelen aan een juiste technische uitvoering van de tangverlossing. De rechtbank kwam echter tot het oordeel dat de arts niet aan zijn verzwaarde stelplicht had voldaan en nam daarom aan dat bij het verrichten van de ingreep (dus) een fout was gemaakt. De rechtbank achtte daarbij van belang dat het operatieverslag summier was over het verloop van de bevalling en dat de arts, onmiddellijk nadat hij van de dwarslaesie bij de baby op de hoogte was geraakt, had nagelaten een aanvullend verslag op te stellen waarin hij het verloop van de verlossing gedetailleerd had vastgelegd. De rechtbank was van oordeel dat vanwege het tijdsverloop dat verzuim niet (meer) kon worden hersteld.

Het hof daarentegen was van oordeel dat de arts wel aan zijn verzwaarde stelplicht had voldaan en wees de vordering af. Het hof overwoog daarbij dat op de aangesproken arts niet de verplichting rustte bewijs te leveren van de feiten die hij had gesteld ter betwisting van de door de moeder gestelde beroepsfout ${ }^{53}$ en dat hij had voldaan aan de plicht om moeder aanknopingspunten te verschaffen voor eventuele bewijslevering. Daarbij achtte het hof van belang dat uit het rapport van de gynaecologisch deskundige volgde dat het OK-verslag voldeed aan de eisen die de beroepsgroep daar destijds aan stelde, ${ }^{54}$ hetgeen voorts door de arts nader was onderbouwd met een rapport van een tweetal gynaecologen, waarvan één hoogleraar. Voorts had de arts in eerste aanleg nauwkeurig verslag gedaan van zijn handelen tijdens de keizersnede. Het hof overwoog daarbij dat op de arts ook niet de plicht rustte het OK-verslag aan te vullen direct na kennisneming van de dwarslaesie.

Door de moeder werd tevergeefs een beroep gedaan op het leerstuk 'res ipsa loquitor' ('de zaak spreekt voor zich'). Zij stelde dat sprake was van zodanig letsel dat daarvoor redelijkerwijs geen andere oorzaak kan worden aangewezen dan een teveel aan tractie bij de uit-

52 HR 16 maart 2018, ECLI:NL:HR:2018:365, NJ 2018, 143 m.nt. J. Legemaate en TvGR 2018/6, p. 607 m.nt. S. Nouwt (Tangverlossing).

53 Vgl. HR 23 oktober 1992, NJ 1992, 813 (Aangetrokken handrem).

54 Dit volgt uit HR 15 juni 2007, NJ 2007, 335 (Ulnaris). 
voering van de tangverlossing. Zij beriep zich daarbij op een rapport van een neonatoloog en een rapport van een neuroradioloog. Mede vanwege de mogelijkheid dat de dwarslaesie voor de geboorte was ontstaan door een infectie met het coxsackievirus was er naar het oordeel van het hof onvoldoende aanleiding om op grond van het letsel onzorgvuldig handelen van de gynaecoloog bij het hanteren van de tang aan te nemen.

De stelling van de moeder dat er sprake was een onzorgvuldig uitgevoerde ingreep omdat het 'bijzonder ongebruikelijk' was bij een keizersnede een tang te gebruiken, hetgeen zij onderbouwde met een partijrapport van een hoogleraar gynaecologie, werd door het hof verworpen. De gynaecologisch deskundige die de rechtbank had benoemd had de visie van de betreffende hoogleraar in zijn rapport weersproken en had in dat kader ook een op dat terrein gespecialiseerde gynaecoloog geraadpleegd.

In cassatie werd door de moeder geklaagd over de bewijslastverdeling en de waardering daarvan door het hof. Beide cassatiemiddelen werden met een beroep op artikel 81 lid 1 Wet RO verworpen.

\subsection{Bewijsgaring}

Deze casus laat zien dat (de advocaten van) beide partijen actief aan de slag waren gegaan om de bewijspositie van hun cliënt te verbeteren. Daarbij had de gynaecoloog in de procedure nauwkeurig verslag gedaan van zijn handelen tijdens de keizersnede. Daarmee had de arts de moeder voldoende aanknopingspunten voor eventuele bewijslevering verschaft. ${ }^{55}$ De rechtbank stelde als aanvullende eis dat aan het verslag van de arts ook relevante bewijswaarde kan worden toegekend. Naar het oordeel van de rechtbank was die te beperkt omdat de arts nadat hij kennisnam van de dwarslaesie had verzuimd een aanvullend verslag op te stellen.

Dit oordeel was naar het oordeel van het hof onjuist. In zijn conclusie tijdens de procedure in cassatie wijst A-G Hartlief er in dit kader op dat een gebrek in de verslaglegging volgens eerdere jurisprudentie van de Hoge Raad kan worden geheeld door een verklaring in het geding te brengen waaruit de gang van zaken tijdens de medische behandeling blijkt. ${ }^{56}$

De advocaat die de belangen van de patiënt behartigt, zal in het kader van de verzwaarde stelplicht zijn pijlen vooral moeten richten op ontbrekende of onvolledige informatie met betrekking tot de lezing van de hulpverlener. Als daarin nauwkeurige informatie over de toedracht ontbreekt, zal dat tot de conclusie kunnen leiden dat niet aan de verzwaarde stelplicht is voldaan. De advocaat van de arts zal zich in dat kader niet alleen moeten richten op het naar voren brengen van informatie die uit het dossier blijkt, maar ook nauwgezet moeten aangeven wat de feitelijke gang van zaken is geweest, zelfs indien dat niet met aantekeningen uit het dossier kan worden onderbouwd. Het gaat daarbij in de eerste plaats om het stellen van relevante feiten. Eerst daarna komt eventuele bewijslastverdeling aan de orde en weer daarna de waardering van het bewijs (is het voldoende, is het geloofwaardig?).

56 Zie r.o. 3.17 en HR 20 april 2007, ECLI:NL:HR:2007:BA1093 (Filshieclip). 
De rechtbank had zich door twee onafhankelijke deskundigen laten voorlichten en de beide advocaten hadden ieder ook weer de nodige partijdeskundigen geraadpleegd. In het kader van de bewijswaardering is voorlichting door deskundigen voor de rechter essentieel. Het juridisch oordeel, waarbij het primair draait om de vraag of de hulpverlener onzorgvuldig heeft gehandeld én, zo ja, of dit tot de gezondheidsschade heeft geleid die de patiënt ondervindt, zal noodzakelijkerwijs immers in veruit de meeste gevallen op de voorlichting door deskundigen zijn gebaseerd. Ook de advocaten zullen zich derhalve van voorlichting door deskundigen moeten voorzien.

\subsection{De preprocessuele bewijsgaring}

Op 20 juni 2020 is het wetsvoorstel Vereenvoudiging en modernisering bewijsrecht bij de Tweede Kamer ingediend. ${ }^{57}$ Daarin wordt een zogeheten "preprocessuele bewijsgaringsplicht' voor partijen geïntroduceerd. Met deze plicht wordt een grote(re) verantwoordelijkheid bij advocaten neergelegd bij de geschilbeslechting. ${ }^{58}$

Partijen moeten reeds in de preprocessuele fase de gegevens verzamelen waarover zij 'redelijkerwijs kunnen beschikken' en die 'redelijkerwijs voorzienbaar van belang zijn voor de beoordeling' van de vordering (art. 21 lid 2 van het wetsvoorstel). In de MvT wordt dit de 'dubbele redelijkheidstoets' genoemd (p. 23). Daarbij wordt erop gewezen dat de vergaringsplicht verder kan gaan indien er sprake is van een informatieasymmetrie, zoals aan de orde is bij een mogelijke 'medische fout'. ${ }^{59}$ Indien niet aan de dubbele redelijkheidstoets is voldaan kan de rechter daar de gevolgen aan verbinden die hem geraden voorkomen.

Met deze preprocessuele bewijsgaringsplicht wordt beoogd 'laksheid' te bestrijden bij de informatievoorziening en het moedwillig achterhouden van relevante informatie. Sinds het Timmer/Deutman-arrest, 35 jaar geleden, kunnen advocaten in medische aansprakelijkheidszaken zich die 'laksheid' echter allang niet meer permitteren. Op hen rustte reeds een preprocessuele 'bewijsgaringsplicht' en het wetsvoorstel zal (in zoverre) in hun werkzaamheden weinig verandering brengen.

\subsection{Inzagerecht versus vertrouwelijkheid}

Het wetvoorstel beoogt ook het 'inzagerecht' te verbeteren. Partijen dienen reeds voorafgaand aan de procedure, en dus zonder rechterlijke tussenkomt, elkaar over en weer van de relevante informatie te voorzien. Dit volgt uit artikel 194 van het wetsvoorstel. Ook dat is in het medische aansprakelijkheidsrecht in feite reeds staande praktijk. Het is gebruikelijk dat partijen de feitelijke informatie waarover zij beschikken en stukken waarop zij in rechte eventueel een beroep wensen te doen zo veel mogelijk voorafgaand aan de procedure uitwisselen om hun respectievelijke standpunten toe te lichten en te onderbouwen. Dat is ook de strekking van de GOMA. ${ }^{60}$

57 Zie Kamerstukken II 2019/20, 35489 nr. 3 (MvT).

58 Zie ook C. Janssens \& V. Hofman, 'Modernisering Bewijsrecht en de rol van de advocaat in de voorfase', Advocatenblad 2018, nr. 7, p. 70-73.

59 Zie MvT, toelichting art. 21.

60 Zie o.a. aanbeveling 14. 
Mr. A.C. De Die, Mr. dr. L.A.P. Arends, Mr. W.K. Bischot, Mr. drs. M.J.J. de Ridder, Mr. dr. W.I. Koelewijn, Mr. dr. M.F. Vermaat \& Mr. T.A.M. van den Ende

Het inzagerecht staat er evenwel niet aan in de weg dat de advocaat zich wel in vertrouwelijkheid door eigen deskundigen kan (blijven) laten voorlichten. Met het inzagerecht wordt niet beoogd dat partijen het dossier van de advocaat van de wederpartij kunnen inzien. ${ }^{61}$ Dit zou ook inbreuk maken op het 'fair trial'-beginsel.

In dit kader kan verwezen worden naar het arrest van het hof Arnhem van 7 augustus 2012,62 waarin de vordering van een patiënt om inzage te verstrekken in een medisch advies dat de beroepsaansprakelijkheidsverzekeraar had ingewonnen werd afgewezen. Het maatschappelijk belang van een verzekerde om zich vrijelijk en zonder vrees voor openbaarmaking voor bijstand en advies tot zijn verzekeringsmaatschappij te kunnen wenden woog zwaarder dan het recht van de patiënt op inzage in het advies.

Uit het Tangverlossing-arrest volgt dat inzagerecht ook niet aan de Wet bescherming persoonsgegevens (Wbp) kan worden ontleend. De vordering van de moeder om inzage in het advies dat van de zijde van het ziekenhuis was ingewonnen bij een radioloog, werd afgewezen. Aan de vordering had de moeder ten grondslag gelegd dat haar via de door haar geraadpleegde neonatoloog ter ore was gekomen dat de radioloog op verzoek van de advocaat van de hulpverlener een notitie had opgesteld. De moeder verzocht tevergeefs om afgifte daarvan.

De Hoge Raad bevestigde dat de moeder dit inzagerecht niet toekwam. Het ging niet om inzage in (feitelijke) medische gegevens van haar zoon, maar om inzage in een medische analyse die een deskundige had opgemaakt op verzoek van de advocaat van de hulpverlener. Onder verwijzing naar een uitspraak van het Europese Hof van Justitie ${ }^{63}$ oordeelde de Hoge Raad dat het hier niet ging om persoonsgegevens in de zin van de $\mathrm{Wbp}$ waarop het inzagerecht van de $\mathrm{Wbp}$ van toepassing is. ${ }^{64}$

Ook langs andere weg kan deze inzage niet worden afgedwongen. Zo verklaarde het Centraal Tuchtcollege recentelijk, op 29 januari 2021, ${ }^{65}$ een klacht tegen een door de aansprakelijke partij eenzijdig geraadpleegde gynaecoloog die had geweigerd zijn rapport aan de patiënt ter inzage te verstrekken, ongegrond. Dit inzagerecht zou naar het oordeel van het Centraal Tuchtcollege inbreuk maken op het recht van een procespartij om de verdediging in vrijheid en beslotenheid voor te bereiden.

\subsection{Afronding}

Willemien Kastelein en Jaap Sijmons hebben als auteurs en wetenschappers een belangrijke en waardevolle bijdrage geleverd aan de ontwikkeling van het gezondheidsrecht. Als advocaten gespecialiseerd in het gezondheidsrecht hebben zij de theorie ook zelf in de praktijk kunnen brengen. Zij hebben daarmee een bijdrage geleverd aan een goede rechtsbedeling op het gebied van het gezondheidsrecht. De hiervoor besproken casus illus-

61 Aangezien een advocaat een verschoningsrecht toekomt, volgt dat reeds uit art. 194 lid 2a van het wetsvoorstel.

62 Hof Arnhem 7 augustus 2012, ECLI:NL:GHARN:2012:BX4091.

63 HvJ EU 17 juli 2014, gevoegde zaken C-141/12 en C-372/12 (YS e.a.), ECLI:EU:C:2014:2081.

64 Aangenomen kan worden dat dit ook geldt voor het inzagerecht op grond van de AVG, zie ook annotatie van J. Legemaate in NJ 2018, 423, nr. 4.

65 CTC 29 januari 2021, ECLI:NL:TGZCTG:2021:42. 
treert dat hoogwaardige belangenbehartiging door gespecialiseerde advocaten op het gebied van het gezondheidsrecht zowel in het belang van de patiënt als van de hulpverlener is.

\section{De rol van de advocatuur in de ontwikkeling van de rechtsverhouding tussen vrijgevestigde medisch specialisten en het ziekenhuis (W.I. Koelewijn)}

\subsection{Inleiding}

De rechtsverhouding tussen vrijgevestigde medisch specialisten en het ziekenhuis heeft de afgelopen decennia niet bepaald in rustig vaarwater verkeerd. Opeenvolgende wijzigingen in de wet- en regelgeving rond de ziekenhuisbekostiging en een telkens terugkerende maatschappelijke discussie over de wenselijkheid van een loondienstverband heeft de rechtsverhouding diverse malen stevig onder druk gezet. In de loop der tijd is de rechtsverhouding daardoor steeds complexer geworden en ligt verdere juridisering op de loer.

In deze bijdrage schets ik aan de hand van enkele bepalende momenten in de rechtsontwikkelingen welke invloed de advocatuur in het algemeen daarop heeft gehad en sta ik in het bijzonder stil bij de rol die zorgadvocaat prof. mr. dr. Jaap Sijmons in het bijzonder daarin heeft vervuld.

\subsection{De schuivende panelen en de rol van de advocatuur}

In de naoorlogse jaren werkten de algemene ziekenhuizen en de vrijgevestigde medisch specialisten aanmerkelijk onafhankelijker van elkaar dan anno 2021 het geval is. De samenwerking was destijds vooral gericht op de directe patiëntenzorg, waarbij het ziekenhuis vooral de rol vervulde van een faciliterend zorgbedrijf waarbinnen de vrijgevestigde medisch specialisten hun zelfstandige praktijken voerden.

Die zelfstandigheid was ook verankerd in diverse bepalingen in de zorgregelgeving. De vrijgevestigde medisch specialist sloot naast het ziekenhuis bijvoorbeeld zelfstandig een geneeskundige behandelovereenkomst met zijn patiënten. Een patiënt had op zijn beurt jegens het ziekenfonds een zelfstandige aanspraak op medisch-specialistische zorg naast een zelfstandige aanspraak op ziekenhuiszorg.

Het ging in beide gevallen om verzekerde aanspraken in natura en om aan die natura-aanspraken te kunnen voldoen sloten ziekenfondsen zogenoemde medewerkersovereenkomsten met zowel de (collectieven van) vrijgevestigde medisch specialisten als met de ziekenhuizen. Het honorarium dat vrijgevestigde medisch specialisten ontvingen voor de geleverde zorg stond daarmee zowel contractueel als financieel volledig los van de ziekenhuisbekostiging.

De rechtsverhouding tussen het ziekenhuis en de vrijgevestigde medisch specialist werd in die periode beheerst door de zogenoemde toelatingsovereenkomst. Het betrof een overeenkomst 'sui generis', waarbij het ziekenhuis de medisch specialist als vrijgevestigde zelfstandig ondernemer onder een aantal voorwaarden ruimte, outillage en ondersteunend medisch personeel ter beschikking stelde, waarmee de vrijgevestigde medisch specialist in 
staat werd gesteld om zijn praktijk in het ziekenhuis uit te oefenen. ${ }^{66}$ Vermeldenswaardig is hier dat het daarvoor gebruikte begrip 'toelating' stamde uit de tijd dat de voornamelijk buiten het ziekenhuis praktiserende medisch specialist het recht had om zijn patiënten op te nemen en te behandelen in het ziekenhuis, dat hiervoor faciliterend optrad. ${ }^{67}$

Met de inwerkingtreding van de Integratiewet op 1 februari 2000 was sprake van de eerste ingrijpende wijziging in de bekostigingsregelgeving die de zelfstandige positie van de vrijgevestigde medisch specialisten en de rechtsverhouding met het ziekenhuis stevig onder druk zette. Door de Integratiewet hadden ziekenfondsverzekerden uitsluitend nog recht op één geïntegreerde verstrekking van medisch-specialistische zorg door of vanwege het ziekenhuis. De bedoeling van de wetgever was dat er een geïntegreerd medisch-specialistisch bedrijf zou ontstaan. ${ }^{68}$

Vanaf dat moment waren de vrijgevestigde medisch specialisten ook niet langer zelfstandige contractpartij van de ziekenfondsen en werden zij voor de honorariuminkomsten meer afhankelijk van de contracten die het ziekenhuis met de ziekenfondsen sloot. De Integratiewet dreigde echter het onbedoelde gevolg te krijgen dat de vrijgevestigde medisch specialisten de (fiscale) status van zelfstandig ondernemer daardoor zouden verliezen en in loondienst van de ziekenhuizen zouden komen, met alle juridische en fiscale gevolgen van dien. ${ }^{69}$

De rol en betekenis van de zorgadvocatuur in dit politiek-bestuurlijke krachtenveld van rechtsontwikkelingen en veranderende zorgregelgeving is mijns inziens groot geweest. Hoewel wijzigingen in de zorgregelgeving uiteindelijk de resultante zijn van politieke en democratische besluitvormingsprocessen, hebben zorgadvocaten die achter de schermen optraden namens de koepel- en brancheorganisaties wel degelijk ook een belangrijke rol vervuld bij het richting geven aan deze rechtsontwikkeling.

De invloed van hun juridische analyses over de bedoelde of onbedoelde juridische impact die voorgenomen veranderingen in de zorgregelgeving zouden kunnen hebben voor bestaande rechtsverhoudingen is mijns inziens groot geweest. Zo zorgde bij de introductie van de Integratiewet de bemoeienis van advocaten ervoor dat er nieuwe (model-)toelatingsovereenkomsten tot stand kwamen waarmee de onbedoelde fiscale en juridische effecten van die wet voor de zelfstandige positie van de vrijgevestigde medisch specialisten ongedaan werden gemaakt.

\subsection{Integrale ziekenhuistarieven leidden wederom tot nieuwe rechtsverhoudingen}

Vijftien jaar na de Integratiewet was er opnieuw sprake van een ingrijpende wijziging in de zorgregelgeving die grote impact zou hebben op de rechtsverhouding tussen vrijgeves-

66 J.H. Hubben \& J.G. Sijmons, 'Herpositionering van ziekenhuis en vrijgevestigd medisch specialist in hun civielrechtelijke verhouding 'TvGR 1999, p. 2-16.

67 C.M.G. Vermeulen, 'Rechtsverhouding tussen ziekenhuizen en specialisten en tussen medisch specialisten onderling; conflictoplossing', in: J.H. Hubben (red.) Rechtsbijstand in de gezondheidszorg, Lochem: de Tijdstroom 1989.

68 J.H. Hubben \& E.W. Meulemans, 'De integratiewet. Gewijzigde verhoudingen ziekenhuis-medisch specialistverzekeraar' TvGR 1999, p. 346-358.

69 M.E. Gelpke, 'De vrijgevestigde specialist BV’ Medisch Contact 2007, 62, nr. 44. 
tigde medisch specialisten en het ziekenhuis. Met deze sprong in de tijd beoog ik overigens geenszins te betogen dat in de tussenliggende periode wel sprake was van rustig vaarwater. Integendeel, de invoering van de DBC-systematiek in 2005, vooruitlopend op de grote zorgstelselwijziging in 2006 met de afschaffing van de ziekenfondsen en de introductie van private zorgverzekeraars, de gereguleerde marktwerking, prestatiebekostiging en vrije prijsvorming, noodzaakten steeds opnieuw tot herijking van de rechtsverhouding tussen de vrijgevestigde medisch specialisten en de ziekenhuizen.

Toen echter in 2015 door de wetgever besloten werd tot afschaffing van de zelfstandige honorariumcomponent in de DBC-tarieven voor de medisch-specialistische zorg en definitief werd overgegaan tot invoering van integrale ziekenhuistarieven, werd het ziekenhuis verder in de positie gebracht van een 'geïntegreerd medisch-specialistisch bedrijf'. Het ziekenhuis diende in het gewijzigde tarief- en declaratiemodel de volledige prijs- en productieafspraken met de zorgverzekeraars te maken, inclusief het specialistenhonorarium. ${ }^{70}$ Aan het zogenoemde 'via-declareren' kwam een einde. De vrijgevestigde medisch specialisten verloren daarmee hun financieel zelfstandige positie en werden voor hun honorarium afhankelijk van de afspraken die zij daarover moesten maken met het ziekenhuis.

Met deze ontwikkeling leek aanvankelijk definitief een einde te komen aan het vrije beroep en zouden de toelatingsovereenkomsten juridisch van kleur verschieten en gaan kwalificeren als arbeidsovereenkomsten. In 2014 was daarmee opnieuw een grote rol weggelegd voor zorgadvocaten als impactadressanten en probleemoplossers. Zorgadvocaten hebben in die periode een groot stempel gedrukt op de ontwikkeling van de rechtsverhouding tussen medisch specialisten en het ziekenhuis en daarnaast op het juridische ontwerp van medisch-specialistische bedrijven.

Anders dan bij de voorgaande wijzigingen die leidden tot aanpassingen in de model-toelatingsovereenkomst en grosso modo een tamelijk eenduidige rechtsverhouding tot gevolg hadden, is vanaf 2015 het juridische landschap in de ziekenhuizen sterk gefragmenteerd geraakt. De medisch-specialistische bedrijven die ontstonden kenden verschillende juridische vormen. Vrijgevestigde medisch specialisten verenigden zich in grote maatschappen of coöperatieve verenigingen en richtten massaal besloten vennootschappen op waarin zij hun zelfstandige medisch-specialistische praktijk inbrachten.

De rechtsverhouding tussen de ziekenhuizen en de nieuwe medisch-specialistische bedrijven laat sinds 2015 ook veel variatie zien. Naast uiteenlopende vormen van samenwerkingsovereenkomsten die het medisch-specialistische bedrijf positioneren als gelijkwaardige samenwerkingspartner van het ziekenhuis en uitgaan van een van oudsher zelfstandige vrijgevestigde praktijkuitoefening, zijn er ook contractuele rechtsverhoudingen ontstaan waarbij het medisch-specialistische bedrijf uitsluitend nog opdrachtnemer is geworden en het ziekenhuis de rol van opdrachtgever vervult.

Bij het juridisch vormgeven van deze (nieuwe) rechtsverhoudingen heeft de advocatuur opnieuw een grote rol vervuld. Dat leidde voor zorgadvocaten ook tot lastige praktijkdilemma's. De wetgever streefde met de invoering van de integrale bekostiging naar het ver- 
groten van belangenparallelliteit tussen het ziekenhuis en de vrijgevestigde medisch specialisten. Vanuit dat doel kwam in diverse ziekenhuizen en collectieven van medisch specialisten de vraag op zorgadvocaten af om beide partijen te begeleiden bij het vormgeven van de nieuwe rechtsverhouding tussen ziekenhuis en medisch-specialistisch bedrijf.

Het optreden namens beide partijen, medisch specialisten en ziekenhuis gezamenlijk, kan enerzijds gezien worden als zeer passend bij de uitgangspunten van de wetgever om samen te zoeken naar oplossingen en het gezamenlijke (collectieve) belang van beide partijen voor de patiëntenzorg. Het staat tegelijkertijd echter op gespannen voet met de inherente partijdigheid die besloten ligt in de advocatuurlijke rol. Dat leverde lastige gedragsrechtelijke dilemma's op voor zorgadvocaten, die in veel gevallen daarom uiteindelijk kozen voor een partijdige positie en ofwel het ziekenhuis bijstonden, ofwel de collectieven van medisch specialisten adviseerden.

De partijdige positie die advocaten innamen en de primaire focus op de belangen van de eigen cliënt in de ontstane juridische lappendeken van samenwerkings- en opdrachtovereenkomsten droeg soms duidelijk de signatuur van bepaalde bekende zorgadvocaten. Zo heeft Sijmons in deze periode veelvuldig opgetreden als de advocaat van ziekenhuisbestuurders en onderhandelde hij met de fiscale adviseurs en advocaten van de vrijgevestigde medisch-specialistische collectieven de overeenkomsten tussen diverse ziekenhuizen en medisch-specialistische bedrijven uit.

De hand van Sijmons is mijns inziens in veel van deze contracten herkenbaar. De accenten die in deze overeenkomsten zijn gelegd op de in de loop van de afgelopen decennia toegenomen wettelijke eindverantwoordelijkheden voor de raden van bestuur komen onmiskenbaar uit de pen van Sijmons. Hij heeft als zorgadvocaat en rechtswetenschapper de ontwikkelingen van het ziekenhuis van faciliterend bedrijf voor vrijgevestigde medisch specialisten naar een geïntegreerd medisch-specialistisch bedrijf van nabij meegemaakt. Bovendien heeft Sijmons een grote rol gespeeld bij het diverse malen herijken van de oude model-toelatingsovereenkomsten en kende hij zodoende als geen ander de juridische voetangels en klemmen waar ziekenhuisbestuurders in conflicten en geschillen met vrijgevestigde medisch specialisten tegenaan zouden kunnen gaan lopen.

De advocatuurlijke hand van Sijmons kenmerkt zich in de ontstane samenwerkings- en dienstverleningsovereenkomsten mijns inziens verder door zijn vaste overtuiging dat ziekenhuizen niet langer faciliterende bedrijven vormen maar geïntegreerde medisch-specialistische bedrijven zijn waarin ziekenhuisbestuurders in zijn ogen de evidente eindverantwoordelijkheid dragen voor de patiëntenzorg. Vanuit die overtuiging heeft Sijmons in veel van deze overeenkomsten stevige accenten gelegd op juist deze wettelijke eindverantwoordelijkheden van ziekenhuisbestuurders voor de kwaliteit, veiligheid en organisatie van de patiëntenzorg en heeft hij voor ziekenhuisbestuurders contractuele instrumenten uitonderhandeld om deze eindverantwoordelijkheden ook waar te kunnen maken. Een terugkerend argument daarbij was, dat als de raad van bestuur uiteindelijk wordt aangesproken op de kwaliteit en veiligheid van de binnen de muren van het ziekenhuis geleverde zorg, hij ook doorzettingsmacht moet hebben. 
Daarnaast kenmerkt de advocatuurlijke hand van Sijmons zich in deze contracten door het zo veel mogelijk verleggen van alle juridische, fiscale en financiële risico's naar de medisch-specialistische bedrijven. Vanuit de kant van de medisch specialisten ontstond mede daarom ook weerstand tegen het 'model Sijmons' en werden in onderhandelingen de scherpe randen daarvan afgehaald om een meer gelijkwaardige en evenwichtiger balans te creëren in de rechtsverhouding tussen het ziekenhuis en het medisch-specialistische bedrijf. Dit laat onverlet dat Sijmons als zorgadvocaat in mijn visie veel invloed heeft gehad op de ontwikkelingen in dit deel van het gezondheidsrecht, de verhouding tussen medischspecialistische bedrijven en de ziekenhuizen.

\subsection{Toekomstige ontwikkelingen}

Hoewel het er even op leek dat de vrijgevestigde medisch specialisten vanaf 2015 met de vorming van medisch-specialistische bedrijven voorlopig in rustiger vaarwater waren gekomen en de rechtsverhoudingen zich in de jurisprudentie van rechtbanken en het Scheidsgerecht voor de Gezondheidszorg langzaam maar zeker verder uitkristalliseren, is er opnieuw zwaar weer op komst.

Medio 2020 heeft het Centraal Planbureau in samenwerking met de Ministeries van VWS en Financiën het beleidsdocument Zorgkeuzes in Kaart 2020 gepubliceerd waarin de ontmanteling van medisch-specialistische bedrijven en een gedwongen overgang van vrije vestiging van de medisch specialisten naar een loondienstverband in de ziekenhuizen als sleutel wordt gepresenteerd voor kostenbesparingen en het elimineren van perverse prikkels in de prestatiebekostiging van de ziekenhuiszorg. ${ }^{71}$

De gedwongen overgang naar een loondienstverband zou in de ambtelijke denklijnen indirect moeten worden afgedwongen via wijzigingen in de Wet marktordening gezondheidszorg en/of daarop gebaseerde lagere regelgeving. De kerngedachte zou dan zijn dat ziekenhuizen uitsluitend nog medisch-specialistische zorg kunnen declareren bij de zorgverzekeraars, indien deze zorg geleverd wordt door medisch specialisten in loondienst.

In Zorgkeuzes in Kaart 2020 wordt er rekening mee gehouden dat deze transitie gepaard zal gaan met stevig juridisch verzet vanuit de vrijgevestigde medisch specialisten en de medisch-specialistische bedrijven en voor de overheid een risico meebrengt op forse schadeclaims. Opnieuw voorzie ik in deze maatschappelijke discussie en rechtsontwikkeling in dit specifieke deel van het gezondheidsrecht een belangrijke rol voor de advocatuur.

Als het zover zou komen zal deze ontwikkeling onvermijdelijk leiden tot een vergaande juridisering van de verhoudingen tussen de ziekenhuizen en de medisch-specialistische bedrijven. Dat is naar mijn oordeel absoluut niet in het belang van de patiëntenzorg. Beter zou de overheid zich daarom kunnen concentreren op het creëren van rustiger vaarwater en de innovatiekracht en het ondernemerschap van vrijgevestigde medisch specialisten kunnen inzetten als aanjager van kwalitatieve verbeteringen en doelmatiger patiëntenzorg.

71 Centraal Planbureau, 'Zorgkeuzes in Kaart. Analyse van beleidsopties van politieke partijen voor de zorg', CPB, Ministerie van Volksgezondheid Welzijn en Sport en Ministerie van Financiën, juli 2020, p. 152 e.v. 


\section{Bezwaar maken kan iedereen (M.F. Vermaat)}

\subsection{Inleiding}

Het gezondheidsrecht vormt een breed palet aan rechtsgebieden die lang niet allemaal rechtstreeks met elkaar zijn verknoopt. Zo houd ik mij wat het gezondheidsrecht betreft eigenlijk alleen bezig met de Zorgverzekeringswet (Zvw), Wet langdurige zorg (Wlz), Wet maatschappelijk ondersteuning (Wmo 2015) en de Jeugdwet. Dat wil zeggen: de indicatiestellingen door het CIZ, besluiten van zorgkantoren en gemeenten, toekenningen door zorgverzekeraars en de daarmee samenhangende persoonsgebonden budgetten (pgb's). Een niche zogezegd.

Op dit rechtsgebied zijn naast een handjevol advocaten de nodige medewerkers van de Stichting MEE en onafhankelijke cliëntondersteuners actief. ${ }^{72}$ Deze laatste twee groepen zijn goed ingevoerd in de hierboven genoemde materiewetten en zijn prima in staat mensen de weg te wijzen in het doolhof aan regeltjes: het zijn materiedeskundigen.

De vraag die dan op kan komen is of er eigenlijk nog wel een rol is voor de advocatuur. In het bestuursrecht is een advocaat in procedures bij de rechtbank ook niet verplicht. En bovendien, iedereen kan bezwaar maken en op internet valt alle informatie ${ }^{73}$ te vinden. Is het dan nog wel nodig om een gespecialiseerde advocaat in te zetten?

Als die vraag negatief wordt beantwoord, zal de Minister voor Rechtsbescherming, Sander Dekker, in zijn handen wrijven. Ik denk echter dat de vraag met een volmondig 'ja' moet worden beantwoord. Niet alleen omdat ik zelf advocaat ben, en mijn brood ermee verdien, maar ook omdat een advocaat onontbeerlijk kan zijn en een toegevoegde waarde biedt die anderen niet bieden. Bijvoorbeeld vanwege de in de Advocatenwet opgenomen kernwaarden die onder meer onafhankelijkheid en partijdigheid garanderen. ${ }^{74}$ Maar toch vooral vanwege de specifieke deskundigheid op het gebied van met name het bestuursrecht.

Aan de hand van een actueel voorbeeld uit de praktijk, het resultaatgericht beschikken in de Wmo 2015, kan dat mooi worden geillustreerd.

\subsection{Resultaat gericht beschikken, wat is dat?}

In de Wmo 2015 is geregeld dat burgers door gemeenten ondersteund worden zodat zij zo lang mogelijk zelfstandig thuis kunnen wonen, zelfredzaam zijn en deel kunnen blijven nemen aan de maatschappij. In de praktijk verzorgt de gemeente het onderzoek en de besluitvorming, maar is de uitvoering van wat er feitelijk als individuele maatwerkvoorziening wordt toegekend veelal uitbesteed aan private aanbieders. Dat mag uiteraard. Die aanbieders zijn (bijvoorbeeld) met de gemeente overeen gekomen ervoor te zorgen dat de burger die daarvoor door de gemeente in aanmerking is gebracht in een 'schoon en leefbaar huis' kan wonen. Of ten behoeve van de zelfredzaamheid begeleiding, trede middenzwaar' krijgt.

Er zijn uiteraard meer rechtshulpverleners op 'mijn' werkterrein actief, maar deze noem ik omdat dit naar mijn inschatting de grootste groep is.

73 Niet alleen de regels zelf, maar ook de toelichtingen daarop, artikelen rechtspraak enzovoort.

74 Art. 10a Advocatenwet, zie ook www.advocatenorde.nl/de-advocaat/kernwaarden-1. 
Wat dat in concreto inhoudt, is daarmee niet direct duidelijk. Het is de bedoeling dat de private aanbieder samen met de cliënt, zoals de burger in de Wmo 2015 wordt benoemd, bepaalt welke activiteiten moeten worden verricht om het beoogde resultaat te behalen. Geschillen raken daardoor verplaatst van de voorkant (de indicatiestelling) naar de achterkant (de uitvoering van het besluit). Is wel sprake van een schoon huis? Zo nee, bij wie moet ik dan terecht? De gemeente, of de aanbieder, of diens onderaannemer?

\subsection{Rechtsbescherming onder druk}

Dat betekent onder (veel) meer dat er een lappendeken in de rechtsbescherming ontstaat. Tegen toekenningbesluiten kan bezwaar worden gemaakt bij het college van B\&W en daarna eventueel (hoger) beroep worden ingesteld bij de bestuursrechter. Over de bejegening door medewerkers van de aanbieder kan worden geklaagd bij de (Nationale) ombudsman, maar bij een geschil over de feitelijke uitvoering van de voorziening door de private aanbieder, (het huis is niet schoon genoeg) moet de burger weer naar de - niet goedkope en traag werkende - burgerlijke rechter. In feite hollen de rechtsbescherming en de rechtszekerheid door deze fragmentering achteruit.

\subsection{Dijkbewaking door de $\mathrm{CRvB}$}

De Centrale Raad van Beroep (CRvB) heeft in een aantal uitspraken in ieder geval een deel van de gaten gedicht. Kort gezegd heeft de Raad uiteengezet hoe op de juiste wijze in kaart moet worden gebracht welke ondersteuning in concreto naar aard en omvang nodig is (de zogeheten 'stappenplan-uitspraak' ${ }^{75}$ en dat besluiten waarin wel de activiteiten en het te behalen resultaat staan, maar niet de omvang (hoeveel uren hulp), in strijd zijn met het rechtszekerheidsbeginsel (vandaar dat deze uitspraak wordt aangeduid als de 'resultaatgericht-indiceren-uitspraak'). ${ }^{76}$

\subsection{Wat voor rechtshulpverlener?}

Omdat ik mij afvroeg welke bijdrage de advocatuur aan deze uitspraken heeft geleverd, heb ik de uitspraken daar eens op nageslagen. Het blijkt dat in de 'stappenplan-uitspraak' wel, maar in de 'resultaatgericht-indiceren-uitspraak' geen advocaat optrad, maar een in de Wmo 2015 gespecialiseerde jurist. In de 'stappenplan-uitspraak' is door de advocaat betoogd dat er geen maatwerk is geleverd en in de 'resultaatgericht-indiceren-uitspraak' heeft de jurist het punt aangedragen dat er sprake is van onvoldoende rechtsbescherming.

In de uitspraken is helaas alleen een korte samenvatting weergegeven van wat de beroepsgronden zijn. Om die reden kan ook niet worden geconcludeerd in welke mate die rechtshulpverleners deze uitspraken hebben 'uitgelokt'. Laat staan of het zijn van advocaat een meerwaarde bood. Niet onbelangrijk is ook dat artikel 8:69 Awb in het tweede lid aangeeft dat de rechter de rechtsgronden (ambtshalve) moet aanvullen, ook als partijen die niet aanvoeren en dat het derde lid bepaalt dat de bestuursrechter ook de feiten kan aanvullen.

Het onderstreept in ieder geval dat het van groot belang is dat niet alleen de feiten juist op een rijtje moeten staan. Ook het 'grotere plaatje' met onderwerpen als rechtszekerheid, 
Mr. A.C. De Die, Mr. dr. L.A.P. Arends, Mr. W.K. Bischot, Mr. drs. M.J.J. de Ridder, Mr. dr. W.I. Koelewijn, Mr. dr. M.F. Vermaat \& Mr. T.A.M. van den Ende

bevoegdheidsverdeling tussen gemeenteraad en college, de actuele stand van de rechtspraak enzovoort, moeten in het oog worden gehouden en te berde worden gebracht.

\subsection{Schets van de 'andere rechtshulpverlener'}

Op dit punt aangekomen, heb ik mij afgevraagd of het zijn van advocaat - met alle daarbij behorende kernwaarden - een noodzaak is om tot goede rechtshulp te komen. Of is het afdoende dat je gewoon een goede rechtshulpverlener bent, een bijter die niet loslaat en zijn juridische kennis op orde heeft? Dat laatste is uiteraard altijd van groot belang. Advocaat of niet.

Hiervoor refereerde ik aan medewerkers van de Stichting MEE en cliëntondersteuners die goed op de hoogte zijn van de materiewetten. Hoe een indicatie gesteld moet worden, welke uitvoeringsregeltjes er zijn en hoe de hazen in de dagelijkse praktijk lopen, is voor hen gesneden koek.

Wat hen echter onderscheidt van advocaten is dat zij minder goed ingevoerd zijn in de algemene juridische en procesrechtelijke leerstukken. Als ik cursus geef aan deze doelgroep blijkt er altijd heel veel belangstelling te zijn voor onderwerpen als rechtsbeginselen, bewijslastverdeling in het bestuursrecht, zorgvuldigheidsvereisten, eisen aan de motivering (zeg maar: de Algemene wet bestuursrecht), maar ook abstractere thema's zoals rechtszekerheid.

Op dat vlak valt er voor hen veel te winnen en voor advocaten veel bij te dragen. Het zou voor rechtshulpverleners een verbetering van de kwaliteit kunnen zijn indien zij een beroep kunnen doen op een advocaat. Andersom kunnen advocaten weer baat hebben bij de specifieke kennis van deze materiedeskundigen.

\subsection{Samenwerken in de eerstelijn}

In mijn praktijk werk ik al langere tijd met meerdere groepen van materiedeskundigen samen, wat voor beide zijden kwalitatieve winst oplevert. Deze vorm van samenwerking is, voor zover ik weet, nog geen gemeengoed. Er zijn wel initiatieven in deze richting. Zo wordt in de pilot 'Samenwerken in de eerstelijn' onderzocht hoe eerstelijnsrechtsbijstandsverleners en de sociale advocatuur beter kunnen samenwerken en gebruikers van gefinancierde rechtshulp sneller de juiste oplossing voor hun probleem krijgen. ${ }^{77}$ Een piketdienst is een van de onderdelen van de pilot. Daarin kunnen deelnemende sociaal advocaten, medewerkers van het Juridische Loket en sociaal raadslieden elkaar gemakkelijk bereiken en overleggen bij complexe juridische vragen, of zaken waarbij onduidelijk is of inzet van een advocaat nodig is. Overleg, en indien nodig, overdracht.

Dat is echter iets anders dan de samenwerking waarop ik doel, te weten dat materiedeskundigen en advocaten samenwerken. Dat zou idealiter tot minder en betere bezwaar- en beroepsprocedures moeten leiden, omdat in een vroeg(er) stadium tot een inhoudelijke oplossing kan worden gekomen. Dan is overigens wel vereist, dat ook de bestuursorganen

77 De pilot is een initiatief van de NOvA in samenwerking met de Raad voor Rechtsbijstand, het Juridisch Loket, Sociaal Werk Nederland en de Vereniging Sociale Advocatuur Nederland. 
bereid zijn om van het toernooimodel ${ }^{78}$ afstand te doen. Want dat is nog lang niet altijd het geval.

De procedures, in de zin van de weg naar een oplossing, kunnen inhoudelijk beter worden omdat de kennis van de materie (hoe onderzoek ik de ondersteuningsbehoefte in de Wmo bijvoorbeeld) en die over de eisen die de Awb aan deugdelijke advisering stelt, samen kunnen komen. Dat is met name bij de gefinancierde rechtshulp een welkom extra. Advocaten die deze rechtshulp verlenen noch hun cliënten beschikken doorgaans namelijk over budget om die materiedeskundigheid in te kopen.

\subsection{Conclusie}

Is er een rol voor de advocaat in bestuursrechtelijke procedures binnen het gezondheidsrecht? Jazeker. Niet zozeer in het op een rijtje zetten van de feiten en stellen dat er onvoldoende is gemotiveerd en onderzocht. De toegevoegde waarde ten opzichte van de materiedeskundigen zit vooral en vooreerst in het bieden van argumentatie van meer fundamentele aard. Dat stelt overigens ook eisen aan de kwaliteit van de advocatuur, maar dat is een onderwerp voor een volgend stuk.

\section{Hoe advocaten een stempel drukken op de zorg (T.A.M. van den Ende)}

\subsection{Inleiding}

Gezondheidsrecht omvat de rechtsregels die betrekking hebben op de gezondheidszorg. Dat maakt het vakgebied heel breed. De fusie van twee ziekenhuizen valt er onder, samenwerkingen tussen zorginstellingen, maar ook de disfunctionerende medisch specialist of zorgverlener, de financiering van zorginstellingen, zorginkoop door zorgverzekeraars en zorgkantoren of de tuchtzaak c.q. strafzaak tegen een arts. Het gezondheidsrecht is verweven met rechtsgebieden zoals het strafrecht, bestuursrecht, civielrecht, arbeids- en ambtenarenrecht, het ondernemingsrecht, het geneesmiddelenrecht, het verzekeringsrecht en het personen- en familierecht.

Maar met een gedegen kennis van een of meer van deze rechtsgebieden ben je er als gezondheidsrechtadvocaat niet. Evenzo belangrijk zijn de verhoudingen binnen de gezondheidszorg. Denk aan toezichthouders vanuit de overheid, maar ook aan brancheverenigingen, de governance, raden van toezicht, medisch-specialistische bedrijven, medische staven, cliëntenraden, bestuurders en het Ministerie van Volksgezondheid, Wetenschap en Sport (VWS) niet te vergeten.

Advocatuur in de zorg is een vak dat landelijk door een schaars aantal advocaten wordt beheerst. Vanuit mijn praktijk en werkomgeving heb ik de eer en het genoegen om nauw samen te werken met twee iconen, advocaten in de zorg: Jaap Sijmons ${ }^{79}$ en Willemien

78 www.rechtspraak.nl/Organisatie-en-contact/Organisatie/Raad-voor-de-rechtspraak/Nieuws/Paginas/Teweinig-ruimte-voor-juridische-innovatie.aspx.

79 Prof. mr. dr. Jaap Sijmons is hoogleraar gezondheidsrecht aan de Universiteit Utrecht en advocaat/partner Zorg bij Nysingh advocaten-notarissen. 
Mr. A.C. De Die, Mr. dr. L.A.P. Arends, Mr. W.K. Bischot, Mr. drs. M.J.J. de Ridder, Mr. dr. W.I. Koelewijn, Mr. dr. M.F. Vermaat \& Mr. T.A.M. van den Ende

Kastelein. ${ }^{80}$ Beiden zwaaien af, beiden drukten onmiskenbaar een juridisch stempel op de zorg. Ik richt mij in deze bijdrage op twee stempels. Voor Sijmons op de marktwerking en regulering, ${ }^{81}$ voor Kastelein op het beroepsgeheim en het verschoningsrecht. ${ }^{82}$

\subsection{Hoofdlijnenakkoorden}

Het financiële beleid van de overheid met betrekking tot de gezondheidszorg wordt voor een kabinetsperiode vastgelegd in het Budgettair Kader Zorg (hierna: BKZ). Het BKZ geeft weer hoeveel financiële middelen voor de opeenvolgende jaren in totaal en per deelsector voor gezondheidszorg beschikbaar zijn, behoudens loon- en prijsaanpassingen. De ziekenhuiszorg is bijvoorbeeld een van de deelsectoren waarvoor in het BKZ een budget wordt vastgesteld. Het sluiten van hoofdlijnenakkoorden is inmiddels een beproefde methode om de uitgaven in de zorg te beteugelen. ${ }^{83}$ Zorgaanbieders en zorgverzekeraars moeten bij het maken van contractafspraken voor een bepaald jaar rekening houden met het voor dat jaar maximaal toegestane groeipercentage. Het gaat daarbij om een landelijk percentage: in individuele gevallen kunnen lagere en hogere groeipercentages overeen worden gekomen, zolang landelijk het toegestane groeipercentage niet wordt overschreden. Als de uitgaven over een bepaald jaar desondanks hoger zijn dan de voor dat jaar beschikbare middelen, kan de minister ervoor kiezen het 'macrobeheersingsinstrument' (hierna: mbi) in te zetten. Hiermee kan de overschrijding worden teruggehaald.

Met dat sanctiemiddel kan de overheid sinds 2012 de zorguitgaven beteugelen. Wordt het jaarlijkse totaalbedrag dat per zorgsector is afgesproken overschreden, dan kan de NZa als 'ultimum remedium' een mbi opleggen aan die hele sector. Dat betekent dat alle zorgaanbieders in die sector, verdeeld naar hun marktaandeel, een bedrag moeten afstaan aan het Zorgverzekeringsfonds (het fonds waar de rijks- en inkomensafhankelijke zorgbijdragen in worden gestort). Het mbi is tot nu toe nog nooit toegepast. Hoofdlijnenakkoorden werken als het gaat om het beteugelen van de kosten voor de zorg. Het effect van de gesloten hoofdlijnenakkoorden strekte echter verder dan de directe bijdrage aan de lagere uitgavengroei.

Met het ondertekenen van de eerste akkoorden hebben de Minister van VWS en de veldpartijen een periode afgesloten van tegenstellingen en onrust. Voordat de akkoorden werden afgesloten, was er sprake van een scherpe stijging van de zorguitgaven en bestuurlijke onrust. De relaties van partijen onderling en ook hun verstandhouding met de overheid

80 Mr. dr. Willemien Kastelein is advocaat/partner Zorg bij Nysingh advocaten-notarissen en was van 1999-2010 bijzonder hoogleraar aan de Radboud Universiteit Nijmegen.

81 Zie bijvoorbeeld: Aanbodregulering en de Wet Toelating Zorginstellingen, (juridisch proefschrift, verdedigd op 6 november 2006, handelseditie Den Haag: Sdu Uitgevers) en Preadvies 2011 Vereniging voor Gezondheidsrecht Stelsel onder stress, 'De cure: transitie en onbalans', Den Haag: Sdu Uitgevers 2011, p. 15-87.

82 Zie bijvoorbeeld: Het beroepsgeheim in rechte. Zwijgen: recht of plicht?, Preadvies 2004 Vereniging voor Gezondheidsrecht, Den Haag: Sdu Uitgevers 2004, p. 145-195 en 'Beroepsgeheim en verschoningsrecht, reikwijdte discussies', TvGR 2019, p. 352-359.

83 (2010) Hoofdlijnen bekostiging vrij gevestigd medisch specialisten transitie 2012-2014, (2011) Bestuurlijk hoofdlijnenakkoord 2012-2015, (2012) Convenant huisartsenzorg 2012/2013, (2012) Bestuurlijk Akkoord Toekomst GGZ 2013-2014, (2013) Onderhandelaarsresultaat medisch-specialistische zorg 2014 t/m 2017, (2013) Onderhandelaarsresultaat eerste lijn 2014 tot en met 2017, (2013) Bestuurlijk akkoord geestelijke gezondheidszorg 2014-2017. 
waren niet altijd goed, mede doordat vaak achteraf 'te veel uitgegeven' geld bij zorginstellingen werd teruggevorderd en omdat veel maatregelen vanuit het ministerie aan de sectoren werden opgelegd. Meer dan eens werd door brancheverenigingen (en individuele leden) al dan niet succesvol geprocedeerd tegen de Staat. ${ }^{84}$

Het is juist die juridische onrust die zorgde voor de omslag bij VWS. Uiteraard waren het de zorginstellingen en/of brancheverenigingen die ten strijde trokken tegen beslissingen van de overheid. Zij werden bijgestaan door advocaten gespecialiseerd in de zorg. Het systeem van de zorg, de van overheidswege begrenzing van de zorguitgaven maar ook de grenzen van het systeem werden door die advocaten samen met hun cliënten getest op houdbaarheid. Met succes.

Hoofdlijnenakkoorden hebben voor bestuurlijke rust en binding gezorgd. ${ }^{85}$ Het veld committeerde zich aan het budgettair kader, wat zorgde voor ruimte voor constructief overleg over het verbeteren van kwaliteit en doelmatigheid. Die bestuurlijke rust heeft grotendeels standgehouden. Al kun je je afvragen of de coronacrisis de panelen zal doen schuiven.

\subsection{Beroepsgeheim en verschoningsrecht}

Het klassieke gezondheidsrecht houdt de advocaat in de zorg van oudsher al bezig. Die principiële juridische vragen zullen altijd blijven. Zoals het beroepsgeheim en het daaraan verbonden verschoningsrecht.

Aan het verschoningsrecht ligt ten grondslag dat het maatschappelijk belang dat de waarheid in rechte aan het licht komt moet wijken voor het maatschappelijk belang dat eenieder zich vrijelijk en zonder vrees voor openbaarmaking van het toevertrouwde om bijstand en advies tot de verschoningsgerechtigde moet kunnen wenden. Ingevolge artikel 98 lid 1 Sv (Wetboek van Strafvordering), mogen bij personen met een bevoegdheid tot verschoning als bedoeld in artikel 218 Sv zonder hun toestemming brieven of andere geschriften waartoe hun plicht tot geheimhouding zich uitstrekt, niet in beslag worden genomen. Wel mogen, ook zonder hun toestemming, in beslag worden genomen brieven of geschriften die voorwerp van het strafbare feit uitmaken of tot het begaan daarvan hebben gediend, nu dergelijke brieven en geschriften geen object zijn van de aan evenbedoelde personen toekomende bevoegdheid tot verschoning.

De aard van de hier aan de orde zijnde bevoegdheid tot verschoning brengt mee dat het oordeel omtrent de vraag of brieven of geschriften object van de bevoegdheid tot verschoning uitmaken, in beginsel toekomt aan de tot verschoning bevoegde persoon. ${ }^{86}$ Wanneer deze zich op het standpunt stelt dat het gaat om brieven of geschriften die noch voorwerp van het strafbare feit uitmaken noch tot het begaan daarvan hebben gediend en waarvan kennisneming zou leiden tot schending van het beroepsgeheim, dient dit standpunt door

84 Vgl. Hof Den Haag 9 november 2010, 200.073.958-01, ECLI:NL:GHSGR:2010:BO3321, GJ 2010/151; CBb 29 januari 2009, AWB 08/30, ECLI:NL:CBB:2009:BH3020, GJ 2009/47; CBb 14 mei 2013, AWB 09/680, ECLI:NL:CBB:2013:CA3053, GJ 2013/110; CBb 27 januari 2010, AWB 09/1429 en AWB 09/1494, ECLI:NL:CBB:2010:BL0808, GJ 2010/32; J.G. Sijmons, 'Kroniek rechtspraak Wet tarieven gezondheidszorg en Wet marktordening gezondheidszorg' TvGR 2007, p. 117-130.

85 Zorgakkoorden, Uitgavenbeheersing in de zorg deel 4, Algemene Rekenkamer 2016.

86 Vgl. HR 29 maart 1994, ECLI:NL:HR:1994:ZC9694, NJ 1994, 537. 
Mr. A.C. De Die, Mr. dr. L.A.P. Arends, Mr. W.K. Bischot, Mr. drs. M.J.J. de Ridder, Mr. dr. W.I. Koelewijn, Mr. dr. M.F. Vermaat \& Mr. T.A.M. van den Ende

de organen van politie en justitie te worden geëerbiedigd, tenzij er redelijkerwijze geen twijfel over kan bestaan dat dit standpunt onjuist is.

Het verschoningsrecht van onder meer de arts is echter in zoverre niet absoluut, dat zich zeer uitzonderlijke omstandigheden laten denken waarin het belang dat de waarheid aan het licht komt - ook ten aanzien van datgene waarvan de wetenschap hem als zodanig is toevertrouwd - moet prevaleren boven het verschoningsrecht. ${ }^{87}$ De beantwoording van de vraag welke omstandigheden als zeer uitzonderlijk moeten worden aangemerkt is niet in een algemene regel samen te vatten. Daarbij geldt voorts dat indien moet worden geoordeeld dat het belang van de waarheidsvinding dient te prevaleren, die inbreuk op het verschoningsrecht niet verder mag gaan dan strikt nodig is voor het aan het licht brengen van de waarheid van het desbetreffende feit. Ik breng onder uw aandacht het arrest van de Hoge Raad uit 2009 waarbij Kastelein als advocaat betrokken was. ${ }^{88}$ Dat arrest is nog altijd van waarde.

Wat was er aan de hand? Een baby komt thuis te overlijden nadat zich eerder een aantal niet goed medisch verklaarde levensbedreigende incidenten hebben voorgedaan waarvoor de baby in het LUMC is behandeld. De moeder van de baby wordt aangemerkt als verdachte. Ondanks dat de ouders toestemming hebben gegeven, wil het LUMC de medische gegevens van de baby niet aan het openbaar ministerie verstrekken. De Hoge Raad stelt voorop dat de aan de arts gegeven toestemming om onder het verschoningsrecht vallende informatie aan derden te verstrekken, het verschoningsrecht niet opheft. De eerdere melding bij het Advies- en Meldpunt Kindermishandeling door het LUMC brengt niet mee dat het de arts in een procedure daarom niet meer vrij zou staan zich op zijn verschoningsrecht te beroepen. Het is niet zo dat de arts of het LUMC destijds categorisch weigerde.

Het LUMC was bereid de patholoog-anatoom van het NFI inzage te geven in de dossiers en was bereid om naar aanleiding van diens bevindingen zich opnieuw te beraden. De Hoge Raad oordeelde dat de rechtbank kon oordelen dat in casu zich niet zodanig bijzondere omstandigheden voordeden dat doorbreking van het verschoningsrecht gerechtvaardigd was en dat vooralsnog niet was uitgesloten dat de gevraagde gegevens op andere wijze konden worden verkregen. De tussenoplossing - het de patholoog-anatoom van het NFI inzage geven in de dossiers en de bereidheid om naar aanleiding van diens bevindingen zich opnieuw te beraden - heeft daar ongetwijfeld aan bijgedragen en is nog altijd een oplossing die tegenwoordig veel wordt benut.

\subsection{Tot slot}

Wat kenmerkt de 'echte' advocaat in de zorg?

Die advocaten trachten cliënten naar mijn stellige overtuiging te loodsen door het veelal juridisch ingewikkelde kader van de zorg, waarbij zij zich richten op oplossingen, met - als

87 Vgl. HR 30 november 1999, ECLI:NL:HR:1999:ZD7280, NJ 2002, 438; HR 29 juni 2004, ECLI:NL:HR: 2004:AO5070, NJ 2005, 273; HR 9 mei 2006, ECLI:NL:HR:2006:AV2386, NJ 2006, 622; HR 27 mei 2008, ECLI:NL:HR:2008:BC1369, NJ 2008, 407 en HR 21 oktober 2008, ECLI:NL:HR:2008:BD7817, NJ 2008, 630. 
dat noodzakelijk is - een principiële vraag of geschil waar uitsluitend met het doorlopen van een procedure een antwoord op kan worden gegeven.

Die advocaten kennen de schuivende panelen in de zorg en weten wat de zorginstellingen ver voor de stelselwijziging van 2006 al bezighield. De zorg is een wereld op zichzelf met juridische uitdagingen te over. De zorgadvocatuur zal Sijmons en Kastelein node missen, niet vergeten. 